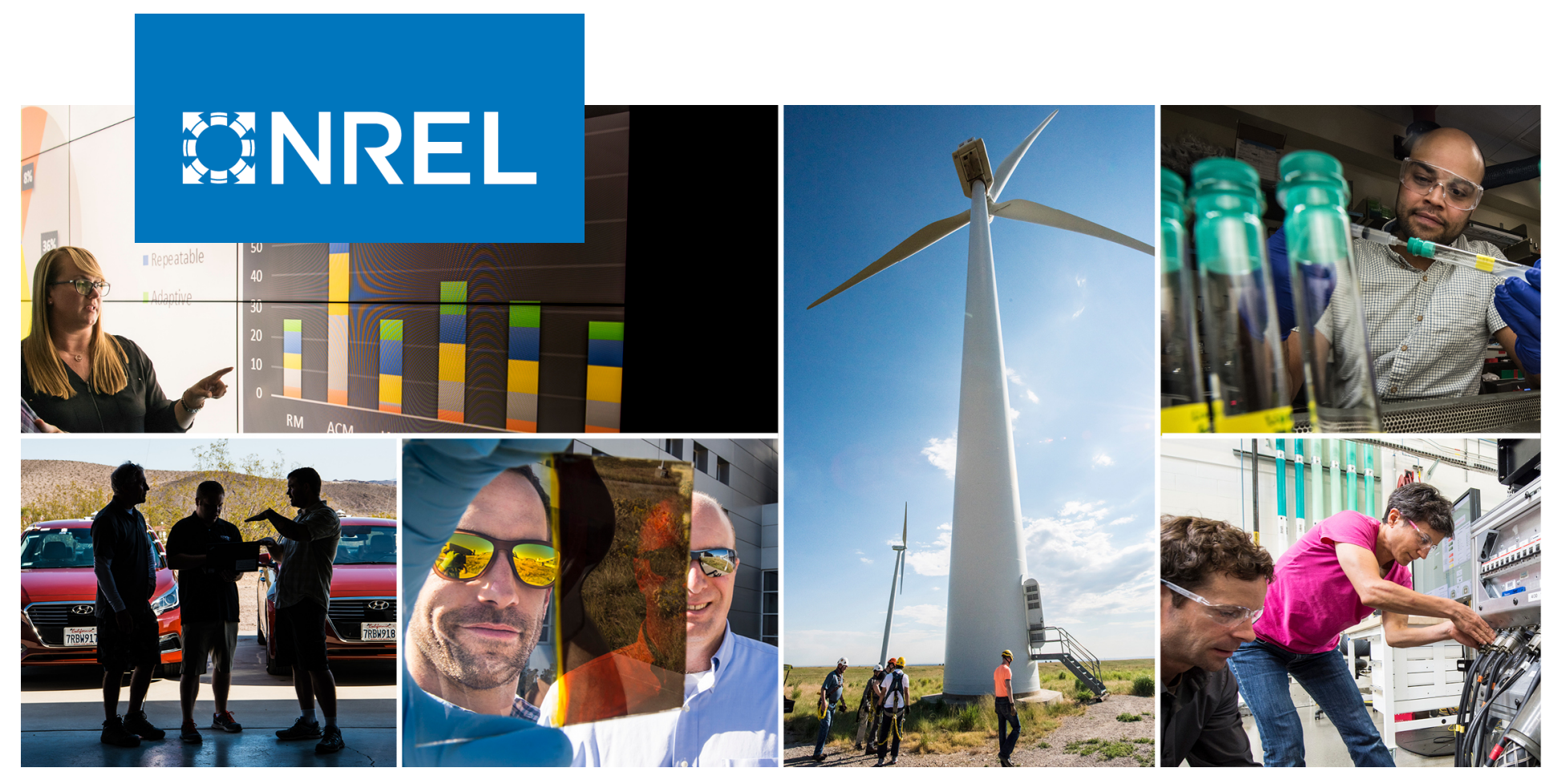

\title{
Catalina Repower Feasibility Study: NREL Phases I \& II Summary Report
}

Kathleen Krah, Michael Callahan, and James Elsworth

National Renewable Energy Laboratory

Produced under direction of Southern California Edison and the U.S. Environmental Protection Agency (EPA) by the National Renewable Energy Laboratory (NREL) under Interagency Agreement No. IAG-16-2012.

NREL is a national laboratory of the U.S. Department of Energy Office of Energy Efficiency \& Renewable Energy

Operated by the Alliance for Sustainable Energy, LLC

This report is available at no cost from the National Renewable Energy Laboratory (NREL) at www.nrel.gov/publications.
Strategic Partnership Project Report NREL/TP-7A40-76779

October 2020 


\title{
GNREL
}

\section{Catalina Repower Feasibility Study: NREL Phases I \& II Summary Report}

\author{
Kathleen Krah, Michael Callahan, and James Elsworth
}

National Renewable Energy Laboratory

\section{Suggested Citation}

Krah, Kathleen, Michael Callahan, and James Elsworth. 2020. Catalina Repower

Feasibility Study: NREL Phases I \& II Summary Report. Golden, CO: National Renewable

Energy Laboratory. NREL/TP-7A40-76779. https://www.nrel.gov/docs/fy21osti/76779.pdf.

NREL is a national laboratory of the U.S. Department of Energy Office of Energy Efficiency \& Renewable Energy Operated by the Alliance for Sustainable Energy, LLC

This report is available at no cost from the National Renewable Energy Laboratory (NREL) at www.nrel.gov/publications.

Contract No. DE-AC36-08GO28308
Strategic Partnership Project Report NREL/TP-7A40-76779

October 2020

National Renewable Energy Laboratory 15013 Denver West Parkway Golden, CO 80401 303-275-3000 • www.nrel.gov 


\section{NOTICE}

This work was authored by the National Renewable Energy Laboratory, operated by Alliance for Sustainable Energy, LLC, for the U.S. Department of Energy (DOE) under Contract No. DE-AC36-08GO28308. Support for the work was also provided by Southern California Edison and the U.S. Environmental Protection Agency (EPA) under Agreement IAG-16-2012. The views expressed in the article do not necessarily represent the views of the DOE or the U.S. Government. The U.S. Government retains and the publisher, by accepting the article for publication, acknowledges that the U.S. Government retains a nonexclusive, paid-up, irrevocable, worldwide license to publish or reproduce the published form of this work, or allow others to do so, for U.S. Government purposes.

This report is available at no cost from the National Renewable Energy Laboratory (NREL) at www.nrel.gov/publications.

U.S. Department of Energy (DOE) reports produced after 1991 and a growing number of pre-1991 documents are available free via www.OSTI.gov.

Cover Photos by Dennis Schroeder: (clockwise, left to right) NREL 51934, NREL 45897, NREL 42160, NREL 45891, NREL 48097, NREL 46526.

NREL prints on paper that contains recycled content. 


\section{Acknowledgments}

This work was jointly funded by Southern California Edison (SCE) and the Environmental Protection Agency (EPA). The authors appreciate the support and collaborative teamwork of the project funders and many individual team members from SCE, EPA, and NV5. Valuable input, guidance, and reviews were also provided by National Renewable Energy Laboratory team members including Emma Elgqvist, Gail Mosey, Dan Olis, Gregg Tomberlin, and Bob Wood. 


\section{List of Acronyms}

$\mathrm{AC}$

$\mathrm{ACF}$

ATB

BESS

BTU

CA

CAISO

CAPEX

$\mathrm{CO}_{2}$

COD

DC

DR

ECM

EE

EIA

EPA

FF-1

FF-2

FF-3

FF-4

FF-5

FF-6

FF-EE

gal

gm

GWh

HP

ITC

$\mathrm{kV}$

$\mathrm{kW}$

$1 b$.

LC-1

LC-CAP

LCC

Li-ion

LNG

$\mathrm{M}$

MACRS

MDO

MERRA

MMBTU

MW

MWh

$\mathrm{NaS}$ alternating current

area cost factor

Annual Technology Baseline

battery energy storage system

British thermal units

California

California Independent System Operator

capital expenditure or capital costs

carbon dioxide

commercial operation date

direct current

demand response

energy conservation measures

energy efficiency

U.S. Energy Information Association

Environmental Protection Agency

fossil fuel scenario \#1

fossil fuel scenario \#2

fossil fuel scenario \#3

fossil fuel scenario \#4

fossil fuel scenario \#5

fossil fuel scenario \#6

fossil fuel scenario with energy efficiency sensitivity

gallons

gram

gigawatt-hours

horsepower

Investment Tax Credit

kilovolts

kilowatts

pound

minimize life cycle cost scenario \#1

minimize life cycle cost scenario with lower PV/BESS capital cost sensitivity

life cycle costs

lithium-ion

liquified natural gas

million

Modified Accelerated Cost Recovery System

marine diesel oil

Modern-Era Retrospective analysis for Research and Applications

million British thermal units

megawatts

megawatt-hours

sodium-sulfur 


$\begin{array}{ll}\text { NASA } & \begin{array}{l}\text { National Aeronautics and Space Administration } \\ \text { NOx }\end{array} \\ \text { NREL } & \text { National Renewable Energy Laboratory } \\ \text { NSRDB } & \text { National Solar Radiation Database } \\ \text { O\&M } & \text { operations \& maintenance } \\ \text { PBGS } & \text { pebbly Beach Generating Station } \\ \text { PV } & \text { present value of revenue required } \\ \text { PVRR } & \text { renewable energy } \\ \text { RE } & 60 \% \text { renewable energy scenario \#1 } \\ \text { RE60-1 } & 100 \% \text { renewable energy scenario \#1 } \\ \text { RE100-1 } & 60 \% \text { renewable energy scenario \#2 } \\ \text { RE60-2 } & 60 \% \text { renewable energy scenario \#3 } \\ \text { RE60-3 } & 60 \% \text { renewable energy scenario with lower PV/BESS capital cost } \\ \text { RE60-CAP } & \text { sensitivity } \\ \text { RE100-CAP } & 100 \% \text { renewable energy scenario with lower PV/BESS capital cost } \\ & \text { sensitivity } \\ \text { RE60-EE } & 60 \% \text { renewable energy scenario with energy efficiency sensitivity } \\ \text { REopt } & \text { Renewable Energy Optimization and Integration tool } \\ \text { S.B. } & \text { Senate Bill } \\ \text { SCAQMD } & \text { South Coast Air Quality Management District } \\ \text { SCE } & \text { Southern California Edison } \\ \text { TMY } & \text { typical meteorological year } \\ \text { UC-1 } & \text { undersea cable scenario \#1 } \\ \text { W } & \text { watts } \\ \text { WIND Toolkit } & \text { Wind Integration National Database Toolkit } \\ & \end{array}$




\section{Executive Summary}

Engineers at the National Renewable Energy Laboratory (NREL) supported Southern California Edison (SCE) and the United States Environmental Protection Agency (EPA) by conducting technical and economic analyses for energy systems at Santa Catalina (Catalina) Island, which is located 22 miles off the coast of Long Beach, California. This effort was part of a broader Repower Catalina Feasibility Study that was also supported by NV5, an engineering consulting firm and project partner to NREL for this analysis. This document describes NREL's technoeconomic modeling and optimization analysis for the first two phases of this project which focus on supply-side generation and energy storage options for Catalina.

SCE's goal for this analysis is to determine a strategy for electricity generation on Catalina Island that results in lower energy costs, improved energy resiliency, and reduced air emissions. EPA goals for this effort are to reduce emissions of air pollution and encourage renewable energy development on contaminated and formerly contaminated lands when such development is aligned with the community's vision for the site.

Currently, an on-island SCE power plant serves the Catalina Island electrical load with 6 reciprocating diesel generators totaling 9.4 MW; 23 propane-fueled microturbines totaling 1.5 MW; and a 1-MW, 7.2-MWh sodium sulfur battery energy storage system (BESS). In 2017, the electricity consumption on the island was $29.1 \mathrm{GWh}$, with an average load of $3.3 \mathrm{MW}$ and peak load of approximately 5.5 MW.

Considering new environmental standards on diesel generator emissions from California's South Coast Air Quality Management District, a 60\% renewable energy target for 2030 laid out in California's Senate Bill 100, SCE's Clean Power Electrification Pathway, and the characteristics of the island's existing diesel generators, SCE is seeking to evaluate the technical and economic implications of different energy technology options to determine a path forward. Phases I and II of the Repower Catalina Feasibility Study, summarized in this document, evaluated the following:

- Interconnection with the mainland via an undersea cable

- On-island fossil fuel generation, including diesel, propane, and/or liquified natural gas (LNG)

- On-island renewable energy (RE) technologies, including solar photovoltaics (PV), wind turbines, and wave energy devices

- $\quad$ BESS to support the above generation technologies

- Initial analysis of the potential impacts of implementing energy efficiency measures

Thus far, results indicate strong techno-economic potential for a mix of on-island diesel and/or propane generators, solar PV, BESS, and energy efficiency measures to help SCE and Catalina achieve their goals compliant with California's emissions and clean energy standards while minimizing electricity life cycle costs (LCC) over the 30-year analysis period. 
The following bullet points summarize key takeaways from Phases I and II of this analysis:

- An undersea cable does not appear cost-competitive with the other options assessed, largely due to its capital cost along with capital costs required to support redundancy in the form of a second undersea cable or on-island generators.

- On-island emissions-compliant diesel generators or a diesel/propane hybrid generator option could cost-effectively support generation and reliability goals for any of the scenarios considered.

- Diesel generators ranging in capacity from 1.49 MW to $2.98 \mathrm{MW}$ were considered and LCC do not significantly vary between these options.

- An all-propane generators scenario has approximately $50 \%$ higher LCC than alldiesel generators but reduces nitrogen oxide (NOx) emissions by over $75 \%$. This higher cost is largely driven by the need for additional fuel storage on the island. However, even once emissions associated with additional barge shipments of fuel are considered, propane options are still likely to have lower total NOx emissions than diesel. It seems plausible that at least one propane generator could be used to replace the propane microturbines with the existing fuel storage and fire suppression system. Moreover, if propane usage for buildings on Catalina is eventually converted to electricity usage, there may be increased flexibility to add or convert to more propane generators for electrical generation. Additionally, despite having lower heat content than diesel, propane fuel benefits from a low shipping cost since the barge delivery tariffs are largely based on weight.

- A hybrid scenario with diesel and propane generators could serve as a costeffective option that reduces NOx emissions by nearly $25 \%$ over an all-diesel scenario and provides fuel flexibility for price hedging. Generator fuel switching or dual-fuel generators could facilitate this option.

- LNG generators appear to be the costliest generator option evaluated, with an LCC 63\% higher than an all-diesel option. This higher LCC is largely driven by higher capital costs for generators and infrastructure upgrades. Additional feasibility studies for this option would be required to more accurately estimate the costs of fuel shipping and infrastructure upgrades.

- Solar PV and BESS could cost-effectively reduce fossil fuel use and emissions on Catalina.

- Minimizing LCC: Even without considering a RE target, PV is cost effective on Catalina. Adding 1.2 MW-direct current (DC) of PV (covering approximately 8 acres) cost-effectively achieves a 5\% annual RE target without changing the LCC of electricity relative to an all-diesel scenario.

- $60 \%$ annual RE target: A $60 \%$ annual RE target on Catalina Island could be met with approximately $15.6 \mathrm{MW}-\mathrm{DC}$ of PV (covering approximately 100 acres) and 
$12 \mathrm{MW} / 90 \mathrm{MWh}$ (approximately 7.5 hours) of additional BESS. Compared to an all-diesel scenario, the LCC could increase by $\$ 71$ million (47\%).

- 100\% annual RE target: To meet $100 \%$ of the electrical load on Catalina with RE, approximately $44 \mathrm{MW}-\mathrm{DC}$ of PV (covering approximately 280 acres) and 36 MW/340 MWh of BESS could be required. Compared to an all-diesel scenario, overall LCC would increase by $\$ 290$ million or more (>275\%) and would likely require additional distribution system upgrades and integration costs not included in this estimate.

- PV and BESS costs assumptions include higher transportation and labor costs associated with Catalina. If lower PV/BESS capital costs can be achieved that are in line with mainland U.S. costs, understandably, overall system LCC decreases for all PV/BESS scenarios and cost-optimal PV/BESS system sizes could be larger. For a $60 \%$ annual RE target, if mainland PV and BESS capital costs could be achieved on Catalina then the overall system LCC could decrease by an estimated $13 \%$. PV and BESS capital costs are likely to continue to decrease over the coming years, making projects more cost effective as they are developed in phases.

- Wind turbines do not appear cost effective versus other options due to the island's low estimated wind resource - a capacity factor of approximately 9.9\%. Wind resource data for potential site-specific wind turbine locations was not available but was estimated using "measure-correlate-predict" analysis.

- Wave energy devices are in an earlier stage of technology readiness and do not appear as cost-effective for Catalina versus other options considered. As the technology matures and costs decrease, SCE could reevaluate the potential for using this technology at Catalina. A pilot demonstration could be considered but is unlikely to reduce LCC of electricity on Catalina at this time.

- An initial example of energy efficiency impacts suggests that a $21 \%$ decrease in modeled electrical load could yield $15 \%-25 \%$ reductions in the LCC of electricity, excluding the cost of energy conservation measures (ECMs). Considering a $60 \%$ annual RE target, such ECMs could also reduce the PV capacity and land requirements to achieve this goal on-island by $21 \%$.

Concurrent with this analysis, NV5 conducted a preliminary energy efficiency, demand response, demand side management, and deferrable loads evaluation for Catalina. The results of this NV5 analysis were not yet available at the time that NREL completed this techno-economic analysis. SCE has indicated additional follow-on analysis phases could include more detailed analysis and optimization of these demand-side energy options, water systems, electric transportation, and building electrification, among others.

This document summarizes the considerations and findings of Phases I and II, focusing on highlevel takeaways from Phase I and more detailed results from Phase II, and discusses a potential path forward for Phase III. 


\section{Table of Contents}

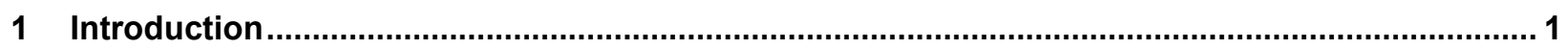

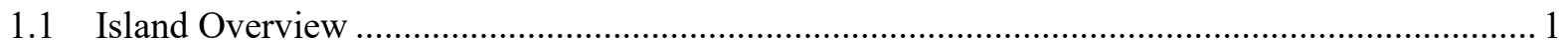

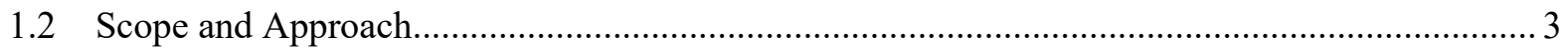

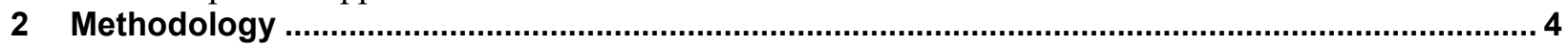

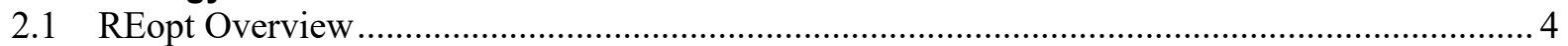

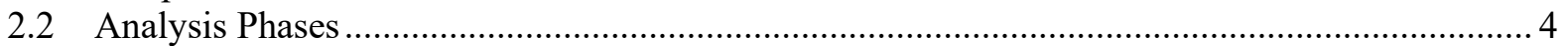

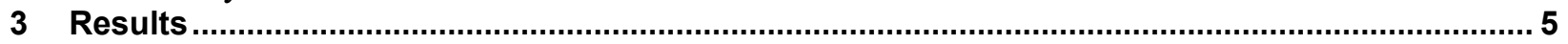

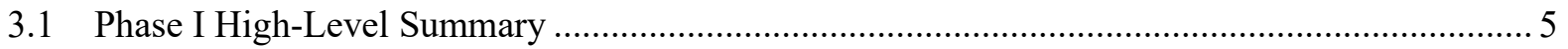

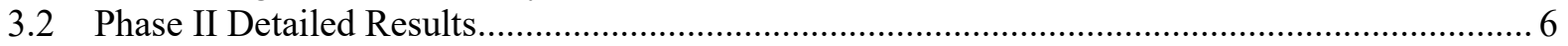

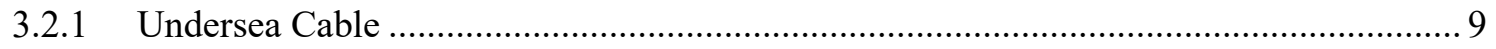

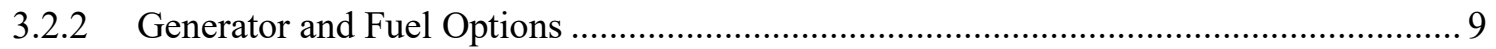

3.2.3 Solar Photovoltaics and Battery Energy Storage Systems .......................................... 10

3.2.4 Wind Turbines and Wave Energy Devices .............................................................. 12

3.2.5 Energy Efficiency: Initial Example............................................................................... 13

4 Discussion: Potential Next Steps Incorporating Load Increases, Load Reductions, and

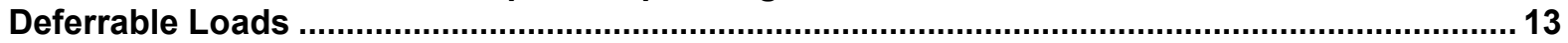

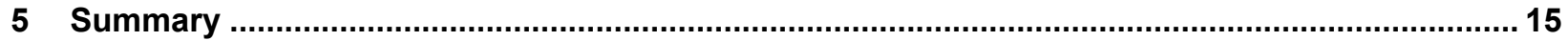

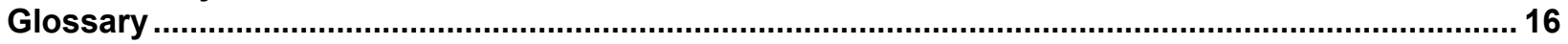

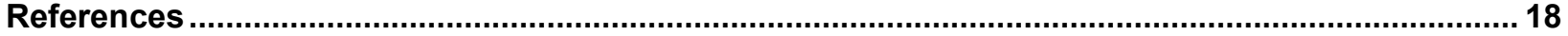

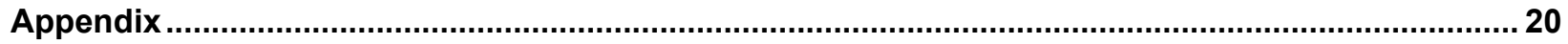




\section{List of Figures}

Figure 1. Map of Catalina Island's generation facility and electric distribution system ........................... 1

Figure 2. Historical hourly electrical load profile, 2015-2017 ............................................................ 2

\section{List of Tables}

Table 1. Existing Generation and Storage Systems .............................................................................. 2

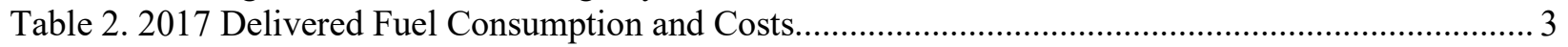

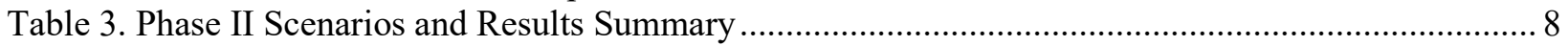

Table 4. Sensitivity to Higher Wind Resource and Lower Wind Turbine CAPEX................................. 12

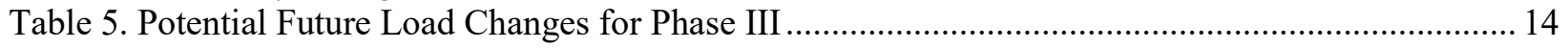

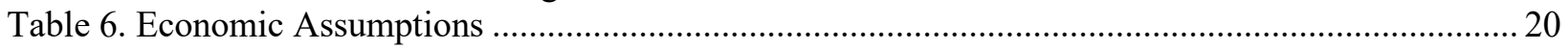

Table 7. Representative Distribution System Upgrade Cost Estimate.................................................. 21

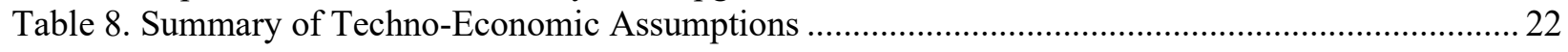




\section{Introduction}

This section provides an overview of Santa Catalina (Catalina) Island, including its electricity consumption, generation strategy, and factors driving this analysis. The scope and approach of the National Renewable Energy Laboratory's (NREL's) techno-economic analysis for Phases I and II are also described in the context of the overall Catalina Repower Feasibility Study.

\subsection{Island Overview}

Catalina Island, located just over 20 miles off the coast of southern California, is home to roughly 4,000 year-round residents, but tourists increase the summer and weekend population to over 10,000, with over 1 million visitors per year (Catalina Island Chamber of Commerce 2020). The island is roughly 48,000 acres of land including over 50 miles of coastline; $88 \%$ of this land is protected by the Catalina Island Conservancy (Catalina Island Chamber of Commerce). Figure 1 shows a map of the island including Southern California Edison's (SCE's) electric generation facilities and distribution system, described below.

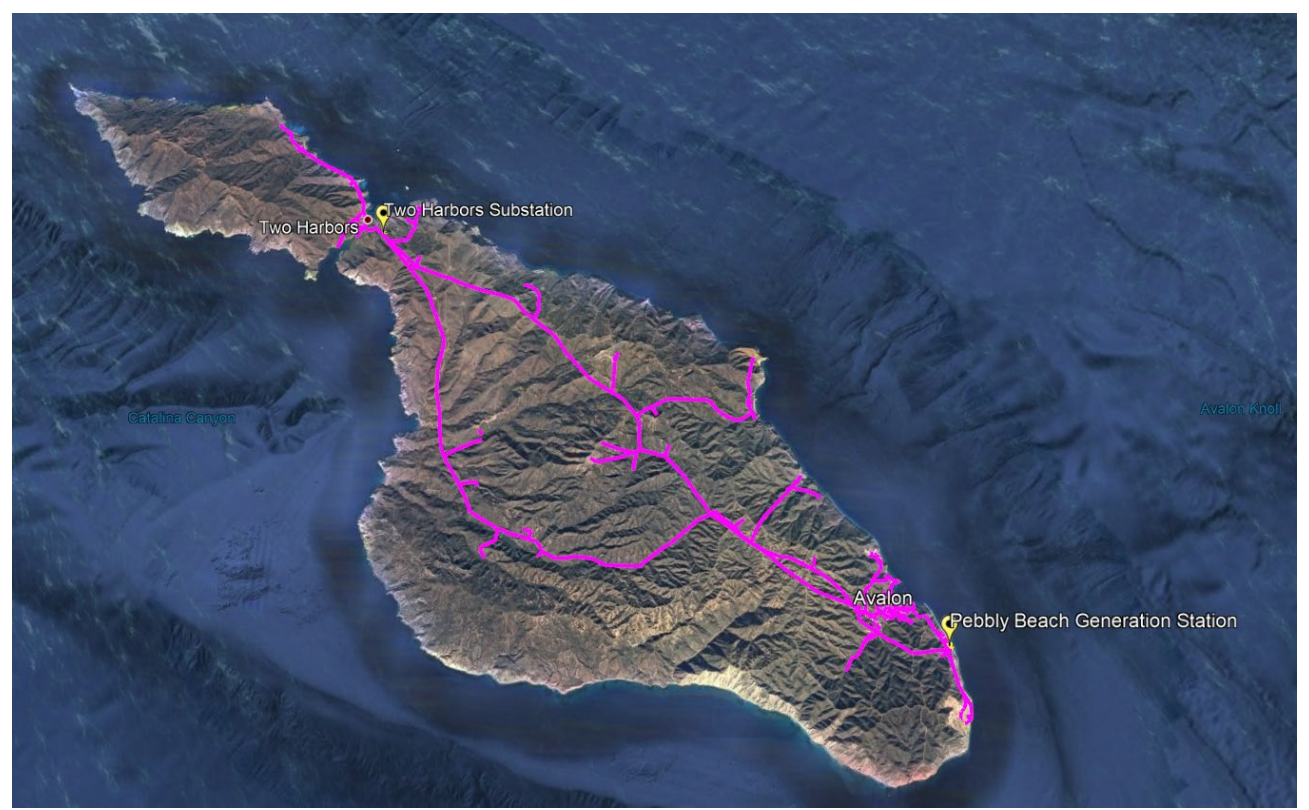

Figure 1. Map of Catalina Island's generation facility and electric distribution system

Source: NV5 (2020)

As a part of Los Angeles County, the island's electricity requirements are served by SCE. The hourly electrical load profile for Catalina is shown in Figure 2. In 2017, the island consumed $29.1 \mathrm{GWh}$ of electricity, with an average load of 3.3 MW and peak load of approximately 5.5 MW. 


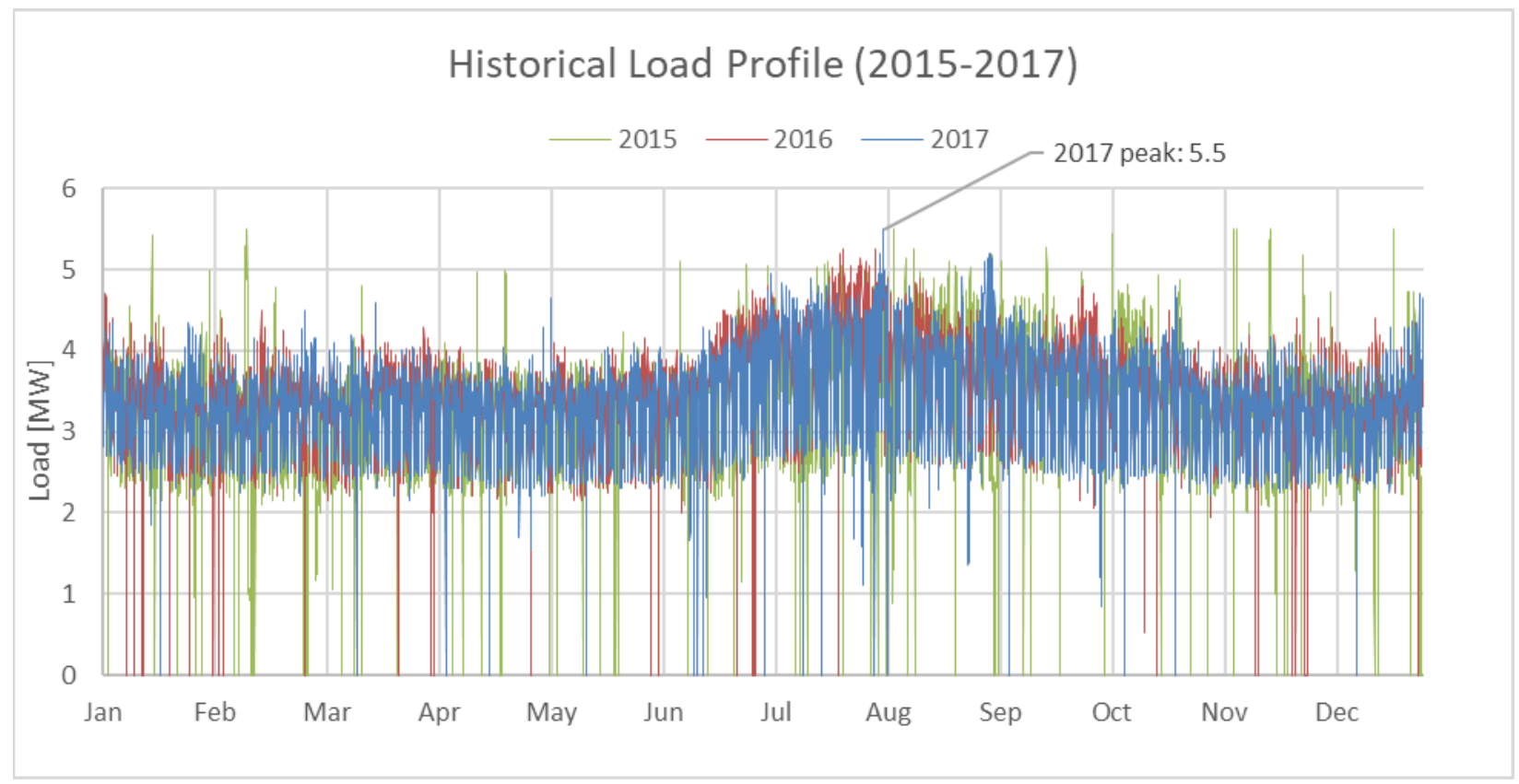

Figure 2. Historical hourly electrical load profile, 2015-2017

Source: SCE (2020)

Currently, SCE generates Catalina's electricity on-island at Pebbly Beach Generating Station (PBGS), which is approximately one mile southeast of the city of Avalon. PBGS consists of six reciprocating diesel generators totaling $9.4 \mathrm{MW}, 23$ propane microturbines totaling $1.5 \mathrm{MW}$, and a 1-MW, 7.2-MWh sodium sulfur (NaS) battery energy storage system (BESS), as summarized in Table 1. Other known on-island generation is customer-sited and privately-owned, the largest being $23 \mathrm{~kW}$ of solar photovoltaics (PV) located at the University of Southern California's Wrigley Marine Science Center. Electricity is distributed across the island via three $12-\mathrm{kV}$ circuits. A second substation is located in the city of Two Harbors.

Table 1. Existing Generation and Storage Systems

\begin{tabular}{cccc}
\hline Unit & Type & Rated Capacity & $\begin{array}{c}\text { Annual Nitrogen } \\
\text { Oxide (NOx) } \\
\text { Emissions (2017) } \\
\text { (tons) }\end{array}$ \\
\hline Unit 7 & Diesel generator & $1 \mathrm{MW}$ & 10.3 \\
\hline Unit 8 & Diesel generator & $1.5 \mathrm{MW}$ & 13.2 \\
\hline Unit 10 & Diesel generator & $1.125 \mathrm{MW}$ & 13.8 \\
\hline Unit 12 & Diesel generator & $1.575 \mathrm{MW}$ & 21.5 \\
\hline Unit 14 & Diesel generator & $1.4 \mathrm{MW}$ & 13.0 \\
\hline Unit 15 & Diesel generator & $2.8 \mathrm{MW}$ & 3.3 \\
\hline Microturbines & Propane microturbines & $23 @ 65 \mathrm{~kW}=1.5 \mathrm{MW}$ & 0.3 \\
\hline BESS & NaS BESS & $1 \mathrm{MW} / \mathbf{7 . 2} \mathrm{MWh}$ & 0 \\
\hline TOTAL & & $\mathbf{1 1 . 9} \mathbf{~ M W}$ & $\mathbf{7 5 . 4}$ \\
\hline
\end{tabular}

This report is available at no cost from the National Renewable Energy Laboratory (NREL) at www.nrel.gov/publications. 
Diesel and propane fuel for these generators is delivered to the island by barge. Table 2 summarizes fuel consumption and costs for 2017; costs include the cost of fuel transport. See the Appendix for more information about fuel delivery and costs. Of the 800,000 gallons (gal) of propane delivered, approximately 20\% (150,000 gal) was consumed by the microturbines (SCE also distributes propane to facilities in the Avalon area via a pipeline).

Table 2. 2017 Delivered Fuel Consumption and Costs

\begin{tabular}{ccc}
\hline Fuel & Diesel & Propane \\
\hline Annual consumption & $2.03 \mathrm{M} \mathrm{gal}$ & $0.80 \mathrm{M}$ gal \\
Annual total cost & $\$ 5.5 \mathrm{M}$ & $\$ 1.3 \mathrm{M}$ \\
& $\$ 2.73 / \mathrm{gal}=$ & $\$ 1.27 / \mathrm{gal}=$ \\
Average cost & $\$ 18.93 / \mathrm{MMBTU}$ & $\$ 17.35 / \mathrm{MMBTU}$ \\
\hline
\end{tabular}

Of the six diesel generators currently operating at PBGS, five are in the range of 33-61 years of age and do not comply with California's South Coast Air Quality Management District (SCAQMD) NOx emissions standards as described in Rule 1135, which defines several compliance options with deadlines ranging from 2022 to 2026 (SCAQMD 2018). Per SCE, the sixth generator, 2.8-MW Unit 15, is exempt from Rule 1135 and could remain operational, but all other existing generators would need to be replaced with new compliant generation. Note that although this analysis focuses on NOx emissions, SCAQMD Rule 1135 also stipulates requirements for other emissions.

Additionally, in 2017, SCE released its Clean Power Electrification Pathway detailing a blueprint to achieve California's environmental goals (SCE 2017). In 2018, California's Senate Bill 100 (S.B.100) set a $60 \%$ renewable energy target for the year 2030. The characteristics of the existing generators and generation plant, current air emissions standards, and SCE's clean power goals serve as the impetus for this analysis.

\subsection{Scope and Approach}

The overall Catalina Repower Feasibility Study evaluated options for Catalina's electric system to provide reliable power to the island while complying with emissions requirements. The team, comprised of SCE, EPA, NV5, and NREL, evaluated the following generation and storage technology options:

- Interconnection with the mainland via an undersea cable

- On-island fossil fuel generation, including diesel, propane, and/or liquified natural gas (LNG)

- On-island renewable energy (RE) technologies, including solar PV, wind turbines, and wave energy devices 


\section{- On-island BESS}

- Initial analysis of the potential impacts of implementing energy efficiency measures

Concurrent with this analysis, NV5 conducted a preliminary energy efficiency (EE), demand response (DR), demand-side management, and deferrable loads evaluation for Catalina. The results of this NV5 analysis were not yet available at the time that NREL completed this technoeconomic analysis. SCE has indicated additional follow-on analysis phases could include more detailed analysis of these demand-side energy options, water systems, electric transportation, and building electrification, among others.

NREL is using the Renewable Energy Optimization and Integration (REopt ${ }^{\mathrm{TM}}$ ) software tool to evaluate the potential of various energy technology options to power Catalina over a 30-year analysis period (Cutler et al. 2017; NREL 2020a). This document describes NREL's technoeconomic analysis and discusses the life cycle cost-effectiveness and other factors of various energy system configurations evaluated. Given the collaborative nature of this effort, the technoeconomic analysis both utilizes results of NV5 analysis as techno-economic inputs and feeds techno-economic results into NV5's analysis.

\section{Methodology}

This section provides an overview of NREL's REopt software tool and of the phased approach taken for this iterative techno-economic analysis.

\subsection{REopt Overview}

REopt is a techno-economic time series optimization modeling tool to support distributed energy systems planning decisions (Cutler et al. 2017; NREL 2020a). Formulated as a mixed integer linear software program, REopt identifies the cost-optimal mix of candidate technologies, their respective sizes, and dispatch strategies.

Typically, the objective function is to minimize the present value of life cycle costs (LCC) of energy over the analysis period by adjusting modeled system sizes and dispatch. The model can optionally incorporate specific RE targets to identify cost-effective pathways to achieve such targets. The LCC modeled include capital costs (CAPEX) of new energy generation and storage capacity, the present value of all operating expenses such as fuel costs and operations and maintenance $(\mathrm{O} \& \mathrm{M})$ costs, and the present value of any financial incentives and depreciation.

The model achieves a balance between energy demand and generation in every time step of the year (hourly time steps were used for this analysis) by sizing and dispatching a cost-optimal combination of power purchases (via a potential sub-sea cable in this case), RE generation, fossil fuel generation, and energy storage. The model also includes specific constraints for each of the identified technology options that define how they can operate.

\subsection{Analysis Phases}

Due to the interdependencies of NREL and NV5 sub-tasks, the techno-economic analysis was performed iteratively, with results informing the next phase of analysis to facilitate 
comprehensive understanding of options and convergence on recommendations for a path forward.

- Phase I: Preliminary Analysis. The preliminary analysis considered initial technical and cost assumptions based on inputs from SCE, EPA, NV5, and NREL. Results were presented in October 2019.

- Phase II: Refined Analysis. Scenarios and technologies considered in Phase II were informed by the results of Phase I and discussion between SCE, EPA, NV5, and NREL. Some technical and cost assumptions were also updated based on Phase I findings, especially where Phase I findings could inform assumptions provided by NV5. Initial results were presented in March 2020.

- Phase III: Refined Analysis including Demand-Side Factors. A future phase of this analysis could fully assess the impact of demand-side considerations on generation-side planning. A Phase III techno-economic analysis could be informed by findings from this Phase II REopt analysis and NV5's initial analysis of potential load increases, load reductions, and controllable loads. This is discussed in more depth in Section 4.

This document summarizes the considerations and findings of Phases I and II, focusing on highlevel takeaways from Phase I and more detailed results from Phase II, and discusses a potential path forward for Phase III.

\section{Results}

\subsection{Phase I High-Level Summary}

A goal of Phase I was to evaluate a range of options at a high level to facilitate team discussions, improve inputs and assumptions for Phase II, and inform selection of scenarios to be assessed in Phase II. Phase I scenarios were collaboratively identified with input from SCE, EPA, NREL, and NV5.

Phase I results yielded the following takeaways:

- Solar PV appears to be cost effective on Catalina.

- Wind turbines do not appear cost effective on Catalina, due to the relatively low estimated capacity factor of $9.9 \%$ predicted from the geospatial wind data and the high capital costs associated with distributed wind on an island with complex terrain. Sitespecific wind resource measurements for possible wind turbine locations were not available but NREL wind experts used "measure-correlate-predict" analysis to identify areas of the island with the strongest resource.

- Additional BESS could stabilize high penetrations of renewables on the island's electric grid.

- Per SCE, microturbines will be decommissioned once they reach end of life in the next several years. 
- An undersea cable interconnecting with the mainland appears more expensive on a life cycle basis than when compared with on-island generation. This is in part driven by its high estimated capital cost of $\$ 220$ million for a single undersea cable, per NV5. A second cable or on-island generation would also be required to provide redundancy, further increasing costs.

\subsection{Phase II Detailed Results}

Based on the findings of and feedback on Phase I, the Phase II analysis incorporated refined techno-economic assumptions, additional technologies and scenarios, and pertinent sensitivity analyses. This section describes the scenarios, considerations, and sensitivities included in the Phase II analysis; for additional details about techno-economic assumptions, see the Appendix.

The load profile used for these analyses is based on the 2017 load profile, which peaks at 5.5 MW, scaled to a peak load of 7 MW per SCE's estimates of load growth. To model this estimated load increase, the electric demand in each hourly time step was increased by $27 \%$ (since $7 \mathrm{MW}$ is a $27 \%$ increase over 5.5 MW peak demand). In future work, additional demandside analysis could be performed to more accurately capture temporal variations in load impacted by future load increases, load reductions, and controllable loads.

To ensure system reliability, spinning reserve requirements and $\mathrm{N}+2$ redundancy requirements were specified as constraints. Spinning reserve requirements are detailed in the Appendix. N+2 redundancy requires that if the two largest generators are offline during the peak load that the remaining generators could still cover the peak load. Renewables and BESS were not assumed to contribute to the $\mathrm{N}+2$ requirement but could support redundancy albeit at higher risk of unavailability.

Table 3 summarizes the scenarios evaluated and the high-level results for Phase II, organized into five categories:

- Undersea Cable (UC)

- Fossil Fuel Only (FF)

- Minimize LCC (LC)

- $60 \%$ RE Annually (RE60)

- $\quad 100 \%$ RE Annually (RE100)

The FF and RE100 options serve as analysis bookends. RE60 is predicated on California's S.B.100 target of $60 \%$ RE by 2030 ; however, off-island options could also support this goal. In order to reduce life cycle costs in LC scenarios, REopt identified the cost-optimal mix of energy technologies to serve Catalina Island's electricity requirements, without considering any renewable energy targets.

Within each of these five categories in Table 3, the individual scenarios listed (in order of increasing LCC) consider different generator configurations and sensitivity analyses. 
- Enumerated scenarios (e.g., FF-1, FF-2, FF-3) vary generator type, number, and size but otherwise use the same load and technology assumptions, as described in the Appendix.

- Lower PV/BESS CAPEX (-CAP) scenarios assume PV and BESS costs are equal to mainland U.S. price points, rather than in the enumerated scenarios where PV and BESS costs are assumed to be higher on Catalina.

- The EE scenarios assume that energy conservation measures (ECMs) are implemented to bring the electrical load profile back to 2017 values - essentially a $21 \%$ decrease in demand applied to all hours of the year. This EE case is intended as one simple example to demonstrate the impact demand-side considerations could have on SCE's generation strategy on Catalina. An additional analysis to include potential load changes and their impact on electricity requirements and generation strategy is recommended and is planned as a Phase III of techno-economic analysis as discussed in Section 4.

Unless otherwise noted, all scenarios assume that the existing 2.8-MW diesel generator (Unit 15) and 1-MW, 7.2-MWh NaS BESS are available for use, with the NaS BESS being replaced at end of life, estimated to occur in 2032. 
Table 3. Phase II Scenarios and Results Summary

\begin{tabular}{|c|c|c|c|c|c|c|c|c|c|c|c|}
\hline \multicolumn{2}{|c|}{ Scenario } & \multirow{2}{*}{$\begin{array}{c}\text { Generator/Fuel } \\
\text { Type }\end{array}$} & \multirow{2}{*}{$\begin{array}{c}\text { Sensitivity } \\
\text { Analysis }\end{array}$} & \multirow{2}{*}{$\begin{array}{c}\text { New }^{\mathrm{a}} \\
\text { Generators } \\
(\mathrm{MW}) \\
4 \times 2.98\end{array}$} & \multirow{2}{*}{$\begin{array}{c}\text { New }^{\mathrm{a}} \\
\text { BESS } \\
\text { Capacity } \\
\text { N/A }\end{array}$} & \multirow{2}{*}{$\begin{array}{c}\text { PV Capacity } \\
\text { N/A }\end{array}$} & \multirow{2}{*}{$\begin{array}{c}\begin{array}{c}\text { Estimated } \\
\text { PV } \\
\text { Footprint }\end{array} \\
\text { N/A }\end{array}$} & \multirow{2}{*}{$\begin{array}{c}\begin{array}{c}\text { Annual } \\
\% \text { RE }\end{array} \\
\text { N/A }\end{array}$} & \multirow{2}{*}{$\begin{array}{c}\text { Estimated } \\
\text { Annual NOx } \\
\text { Emissions }^{b} \\
\text { N/A }\end{array}$} & \multirow{2}{*}{$\begin{array}{l}\text { Estimated } \\
\text { CAPEXc } \\
\\
\$ 263 \mathrm{M}\end{array}$} & \multirow{2}{*}{$\begin{array}{c}\text { Present } \\
\text { Value of } \\
\text { Estimated } \\
\text { LCC } \\
\\
\$ 334 \mathrm{M}\end{array}$} \\
\hline 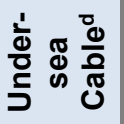 & UC & & & & & & & & & & \\
\hline \multirow{7}{*}{ 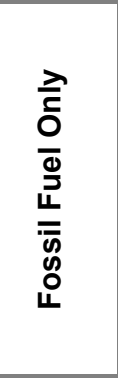 } & FF-EE & Diesel (larger) & EE & $3 \times 2.98$ & \multirow{7}{*}{$\mathrm{N} / \mathrm{A}$} & \multirow{7}{*}{ N/A } & \multirow{7}{*}{$\mathrm{N} / \mathrm{A}$} & \multirow{7}{*}{ N/A } & 20 tons & $\$ 32 \mathrm{M}$ & $\$ 128 \mathrm{M}$ \\
\hline & FF-1 & Diesel (smaller) & --- & $6 \times 1.49$ & & & & & 25 tons & $\$ 32 \mathrm{M}$ & $\$ 152 M$ \\
\hline & FF-2 & $\begin{array}{l}\text { Diesel (larger) } \\
\text { and Propane }\end{array}$ & --- & $\begin{array}{c}3 \times 2.98+ \\
1 \times 1.38 \\
\end{array}$ & & & & & 19 tons & $\$ 44 M$ & $\$ 165 M$ \\
\hline & FF-3 & Diesel (larger) & --- & $4 \times 2.98$ & & & & & 25 tons & $\$ 43 M$ & $\$ 168 \mathrm{M}$ \\
\hline & FF-4 & $\begin{array}{l}\text { Diesel (mixed), } \\
\text { no unit \#15 (2.8 } \\
\text { MW) }\end{array}$ & --- & $\begin{array}{c}2 \times 1.49+ \\
2 \times 2.23+ \\
2 \times 2.98 \\
\end{array}$ & & & & & 25 tons & $\$ 48 M$ & $\$ 169 M$ \\
\hline & FF-5 & Propane & --- & $7 \times 1.38$ & & & & & 6 tons & $\$ 108 \mathrm{M}$ & $\$ 230 \mathrm{M}$ \\
\hline & FF-6 & $\mathrm{LNG}^{\mathrm{e}}$ & --- & $4 \times 2.5$ & & & & & 3 tons & \$132M+ & \$247M+ \\
\hline \multirow{2}{*}{ 主 } & LC-CAP & Diesel (larger) & $\begin{array}{c}\text { Lower PV/BESS } \\
\text { CAPEX }\end{array}$ & $4 \times 2.98$ & $\begin{array}{l}2.2 \mathrm{MW} \\
1.1 \mathrm{MWh}\end{array}$ & $3.8 \mathrm{MW}-\mathrm{DC}$ & 24 acres & $16 \%$ & 21 tons & $\$ 50 M$ & $\$ 165 M$ \\
\hline & LC-1 & Diesel (larger) & --- & $4 \times 2.98$ & 0 & 1.2 MW-DC & 8 acres & $5 \%$ & 24 tons & $\$ 46 \mathrm{M}$ & $\$ 168 M$ \\
\hline \multirow{5}{*}{ 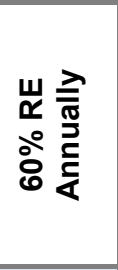 } & RE60-EE & Diesel (larger) & EE & $3 \times 2.98$ & $\begin{array}{l}9 \mathrm{MW}, \\
71 \mathrm{MWh}\end{array}$ & 12.3 MW-DC & 78 acres & \multirow{5}{*}{$60 \%$} & 8 tons & $\$ 127 \mathrm{M}$ & $\$ 194 M$ \\
\hline & RE60-CAP & Diesel (larger) & $\begin{array}{c}\text { Lower PV/BESS } \\
\text { CAPEX }\end{array}$ & $4 \times 2.98$ & \multirow{4}{*}{$\begin{array}{l}12 \mathrm{MW} \\
90 \mathrm{MWh}\end{array}$} & \multirow{4}{*}{ 15.6 MW-DC } & \multirow{4}{*}{99 acres } & & 10 tons & $\$ 126 \mathrm{M}$ & $\$ 211 M$ \\
\hline & RE60-1 & Diesel (smaller) & --- & $6 \times 1.49$ & & & & & 10 tons & $\$ 149 \mathrm{M}$ & $\$ 223 M$ \\
\hline & RE60-2 & Diesel (larger) & --- & $4 \times 2.98$ & & & & & 10 tons & $\$ 159 \mathrm{M}$ & $\$ 243 M$ \\
\hline & RE60-3 & Propane & --- & $7 \times 1.38$ & & & & & 2 tons & $\$ 224 \mathrm{M}$ & $\$ 302 M$ \\
\hline \multirow{2}{*}{ 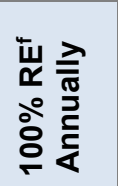 } & RE100-CAP & Diesel (larger) & $\begin{array}{c}\text { Lower PV/BESS } \\
\text { CAPEX }\end{array}$ & $4 \times 2.98$ & \multirow[b]{2}{*}{$\begin{array}{l}36 \mathrm{MW} \\
340 \mathrm{MWh}\end{array}$} & \multirow[b]{2}{*}{$44 \mathrm{MW}-\mathrm{DC}$} & \multirow[b]{2}{*}{279 acres } & \multirow[b]{2}{*}{$100 \%$} & 0 tons & $\$ 291 \mathrm{M}+$ & $\$ 354 M+$ \\
\hline & RE100-1 & Diesel (larger) & --- & $4 \times 2.98$ & & & & & 0 tons & $\$ 395 \mathrm{M}+$ & $\$ 458 \mathrm{M}+$ \\
\hline
\end{tabular}

a Unless otherwise noted, all scenarios assume the existing exempt 2.8-MW diesel generator (Unit 15) and 1-MW, 7.2-MWh NaS BESS are available for use.

${ }^{b}$ Annual NOx emissions listed only account for those emitted during generator operations; they do not include NOx emissions associated with fuel shipments.

${ }^{\circ}$ CAPEX listed includes upfront capital costs of generation and storage technologies, capital costs for distribution system upgrades as estimated by NV5, and capital costs of BESS replacement in year 10.

d Undersea cable and $100 \%$ RE scenarios include diesel generators to satisfy N+2 redundancy requirements but only operate as backup as modeled.

e Additional fuel shipping costs and infrastructure upgrades may be required for LNG; additional feasibility analysis is recommended to refine cost assumptions.

LNG infrastructure cost estimates are assumed greater than or equal to propane infrastructure cost estimates.

${ }^{f}$ Additional integration costs are likely for $100 \%$ RE scenario.

This report is available at no cost from the National Renewable Energy Laboratory (NREL) at www.nrel.gov/publications. 


\subsubsection{Undersea Cable}

The capital ( $\$ 220$ million) and O\&M costs ( $\$ 5$ million) of the undersea cable were evaluated by NV5. California Independent System Operator (CAISO) day-ahead electricity costs from the Huntington Beach substation were used to estimate the cost of mainland generation that would supply Catalina Island through the cable. The undersea cable is assumed to be backed up by onisland diesel generators in this scenario (see UC) which adds additional capital and O\&M costs to this scenario. The LCC of electricity with an undersea cable is nearly $200 \%$ of the LCC of electricity in an all-diesel scenario (see FF-3).

\subsubsection{Generator and Fuel Options}

In order to satisfy $\mathrm{N}+2$ redundancy requirements, all scenarios evaluated have on-island fossil fuel generation to cover the full peak load even if the two largest generators go offline. Three fuel types (diesel, propane, and LNG) and several generator sizes and configurations were evaluated. Note that additional factors beyond those included in the techno-economic analysis, including generator footprint, renewables integration, part load operations, ramp rates, implementation schedule, and spare parts requirements, may also influence generator selection and are not included in this results table.

\subsubsection{Diesel Generators}

Results suggest diesel generation as a lower-LCC option than the other fossil fuel generator options, with a small difference in LCC between smaller (1.49 MW; see FF-1), larger (2.98 MW; see FF-3), or mixed-capacity (1.49 MW, 2.23 MW, and 2.98 MW; see FF-4) generators.

The higher LCCs shown in Table 4 can be attributed to the difference in total generator capacity between the scenarios because diesel generator capital and O\&M costs were estimated on a constant $\$ / \mathrm{kW}$ basis, as well as the fact that Unit 15 was excluded from the mixed-capacity scenario (see FF-4) per request from SCE which therefore required additional new generation capacity to be purchased. However, the larger generators operate at a slightly higher efficiency than the smaller generators. Note that the full range of diesel generators evaluated appear flexible enough in their partial load and minimum loading requirements to be able to facilitate at least $60 \% \mathrm{RE}$ according to input provided by NV5.

\subsubsection{Propane Generators}

An all-propane scenario (see FF-5) has an LCC that is approximately $40 \%$ higher than all-diesel generators but reduces NOx emissions by over $75 \%$. A combined diesel and propane option (see FF-2) could serve as a cost-effective system that reduces NOx emissions by nearly $25 \%$ over an all-diesel scenario and provides fuel flexibility for price hedging.

Potential generator fuel-switching or dual fuel options could be considered to facilitate this option; it could be possible to convert the diesel generators to $95 \%$ propane. Having multiple fuel options and generators could also provide a hedge against cost increases for either propane or diesel fuel.

Even once emissions associated with additional barge shipments of fuel to the island are considered, propane options are still likely to have total lower NOx emissions. Propane has a higher energy intensity by weight although it has a lower energy intensity by volume. Thus, 
Catalina's weight-based fuel shipping rates give propane a shipping cost advantage over diesel. See the Appendix for more details on fuel shipments and emissions implications.

One challenge is that propane fuel storage on the island may be limited by fire suppression requirements and other factors. Nevertheless, it seems plausible that at least one propane generator could be used to replace the propane microturbines with the existing fuel storage and fire suppression system. Additionally, if the propane usage in buildings on Catalina is eventually converted to electricity usage, there may be increased flexibility to add or convert to more propane generators to generate electricity.

\subsubsection{Liquefied Natural Gas Generators}

LNG (see FF-6) appears to be the most expensive generator option evaluated, with an LCC 63\% higher than an all-diesel option. This higher LCC is largely driven by estimated higher total capital costs for generators and infrastructure upgrades. Additional feasibility studies for this option would be required to more accurately estimate the costs of fuel shipping and infrastructure upgrades.

\subsubsection{Solar Photovoltaics and Battery Energy Storage Systems}

Solar PV and BESS appear to be cost effective technologies on Catalina. This section discusses the recommended PV and BESS systems and their economics for scenarios seeking to minimize LCC or achieve $60 \%$ or $100 \%$ RE annually, while considering capital cost and land lease cost sensitivities.

NV5 conducted an analysis to estimate the costs to accommodate increased variable RE generation and potential locations and configurations (e.g. alternating current [AC]-connected versus DC-connected, distributed versus centralized) on Catalina's electric system. These distribution system upgrade cost estimates are included in the capital costs and LCCs listed in Table 4; additional details are provided in the Appendix.

\subsubsection{Minimizing Life Cycle Costs}

$\mathrm{PV}$ is cost-effective on Catalina. Initial analysis suggests that $1.2 \mathrm{MW}$-DC could be supported by the existing NaS BESS (see LC-1) without changing the LCC of electricity relative to an alldiesel scenario (see FF-3) and assuming 76.5\% higher PV capital costs and $31.5 \%$ higher BESS capital costs on Catalina vs. the mainland. Such a system could achieve a 5\% annual RE penetration and reduce annual NOx emissions by 4\%-5\% relative to the all-diesel scenario (see FF-3). The actual most cost-effective size of a PV system will depend on actual PV pricing and project costs.

\subsubsection{60\% Annual Renewable Energy Target}

A $60 \%$ annual RE target on Catalina Island could be achieved with approximately 15.6 MW-DC of PV and $12 \mathrm{MW} / 90 \mathrm{MWh}$ (approximately 7.5 hours) of additional BESS (see RE60-1). This PV system could require approximately 100 acres of land. Compared to an all-diesel scenario (see FF-3), NOx emissions would decrease by 15 tons/year to 10 tons/year, but the life cycle cost could increase by $\$ 71$ million (47\%). This system represents a high contribution of RE, nearly $200 \%$ of the $7-\mathrm{MW}$ peak load on a capacity basis and would require controls and 
communications systems to integrate with the power system. Rough cost estimates for integration are included but could be higher than estimated.

If mainland PV and BESS capital costs could be achieved on Catalina, capital costs could be reduced by $\$ 33$ million, leading to a $13 \%$ reduction in system LCC (see RE60-CAP and Section 3.2.3.4).

\subsubsection{100\% Annual Renewable Energy Target}

A $100 \%$ annual RE target was assessed for this analysis. To meet $100 \%$ of the electrical load on Catalina with RE, approximately $44 \mathrm{MW}-\mathrm{DC}$ of PV and $36 \mathrm{MW} / 340 \mathrm{MWh}$ of BESS could be required. This PV system would require approximately 280 acres of land but could reduce NOx emissions to zero. Relative to an all-diesel scenario (see FF-3), overall LCC increase by $\$ 290$ million or more to over $\$ 458$ million, which is $\$ 215$ million more than the $60 \%$ annual RE scenario (see RE60-1). These estimates only include NV5's distribution system upgrade cost estimate to facilitate $60 \% \mathrm{RE}$; additional distribution system upgrades are likely required to achieve $100 \%$ RE but these additional costs were not estimated or included.

If mainland-based PV and BESS capital costs can be achieved, capital costs could be reduced by $\$ 104$ million, leading to a 23\% reduction in system LCC (see RE100-CAP and Section 3.2.3.4).

Note that REopt was given the option of identifying a combination of solar PV, wind turbines, wave energy devices, and BESS to achieve this 100\% RE target, but only selected PV and BESS to achieve the target at lowest life cycle cost. See Section 3.2.4 for further discussion of wave and wind energy potential and challenges on Catalina.

\subsubsection{Photovoltaics and Battery Energy Storage System Capital Cost Sensitivity}

As mentioned in Sections 3.2.3.1-3.2.3.3, a PV and BESS capital cost sensitivity study was performed to evaluate the impact of capital costs on recommended systems and estimated LCC. Because the base case PV and BESS capital cost assumptions include an area cost factor (ACF) to account for the costs of transportation to and labor on Catalina Island, this sensitivity analysis assessed the implications of achieving mainland costs. PV and BESS capital costs are likely to continue to decrease over the coming years, making projects more cost effective as they are developed in phases.

Removing the ACF from PV and BESS cost assumptions has the following impacts:

- When minimizing LCC without considering any RE target (see LC-CAP), the costeffective RE annual contribution increases from $5 \%$ to $16 \%$. The system size is constrained by NV5-estimated distribution system upgrade costs rather than the cost of the PV/BESS systems themselves. Without considering the distribution system upgrade cost estimates provided by NV5, the estimated PV system size increases to up to 7.6 MW-DC, which could achieve an annual RE contribution of $30 \%$.

- Overall system LCC for the 60\% RE scenario (see RE60-CAP) could decrease by 9\%.

- Overall system LCC for the 100\% RE scenario (see RE100-CAP) could decrease by $23 \%$. 


\subsubsection{Land Lease Cost}

A sensitivity analysis on land lease costs was conducted to help inform land use planning for PV arrays.

\subsubsection{Wind Turbines and Wave Energy Devices}

Wind turbines and wave energy devices were considered in all the scenarios listed in Table 3 but were not found to be as life cycle cost effective when compared to other options. These technologies and their challenges for Catalina Island are discussed below.

\subsubsection{Wind Turbines}

Wind turbines did not appear cost effective on Catalina given the assumptions used for this analysis. This is due to the relatively low capacity factor of $9.9 \%$ observed from the geospatial wind data and the high capital costs associated with distributed wind on an island with complex terrain. Wind resource data for specific possible wind turbine locations was not available but was estimated using "measure-correlate-predict" analysis.

A sensitivity analysis on wind resource and turbine capital costs was performed to consider uncertainty in these values. The wind resource was varied across a range of profiles with average wind speeds up to 2.2 times those observed in available data. Capital costs were reduced up to $50 \%$. As shown in Table 4, wind may become cost-effective on Catalina with a $220 \%$ increase in average wind speed for the sites identified with the highest wind resource on Catalina supplemented by a $50 \%$ reduction in capital costs.

Table 4. Sensitivity to Higher Wind Resource and Lower Wind Turbine CAPEX

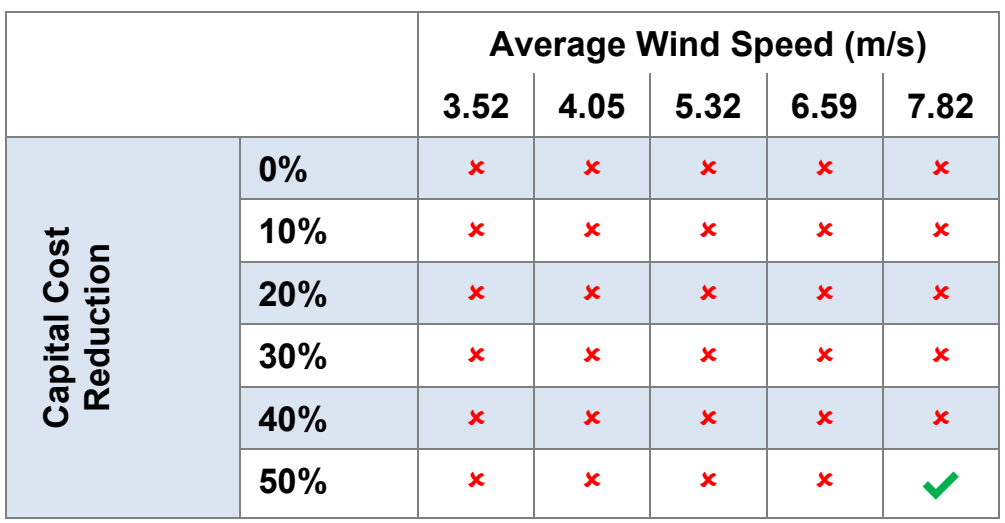

$x=$ not cost-effective $V=$ cost-effective

\subsubsection{Wave Energy Devices}

Wave energy does not appear to be life cycle cost effective on Catalina compared to the other options evaluated and given the assumptions used for this analysis. However, wave energy is an emerging technology with fewer MW deployed in comparison to the other options considered, which has several implications for this analysis and future planning.

Cost and technical assumptions used in this analysis are based on numbers provided by a wave energy vendor. These costs and performance assumptions were not able to be verified by NREL; the costs appear lower and performance appears higher than other wave energy devices NREL 
has assessed. Even using the vendor's assumptions, wave power was not found to be life cycle cost effective compared to the other options at Catalina. Moreover, concerns have been expressed with siting the wave energy infrastructure at Catalina.

However, given its early stage of technology readiness, wave energy could potentially become feasible or even cost effective in the future, pending developments in technology and reductions in costs.

Additional due diligence and evaluation of pilot projects could reduce the risks and confirm cost and generation assumptions. Wave energy device performance is highly device-specific (the industry has not converged to a particular technology) and site-specific. If wave energy is of interest for Catalina island, a smaller pilot demonstration could be considered to de-risk the reliability concerns associated with a technology that is considerably less mature than PV.

\subsubsection{Energy Efficiency: Initial Example}

Phase III of the techno-economic analysis can focus on the impact of demand-side factors, including load increases, load reductions, and controllable loads. However, leading into Phase III, NREL conducted an initial scenario analysis to demonstrate how demand-side considerations could impact SCE's generation strategy on Catalina. For this example of EE impacts, the electric load in each time step was decreased by $21 \%$ to reduce it to 2017 values.

The assumed load reduction could yield $\$ 25$ million-\$40 million (15\%-25\%) reductions in LCC, achieved by reducing the number of generators required to support the load and by reducing annual fuel consumption (see FF-EE). Additionally, it could reduce the PV capacity required to meet the $60 \%$ annual RE goal by $3.3 \mathrm{MW}-\mathrm{DC}$, reducing LCC by $\$ 49$ million $(20 \%)$ and PV footprint by 21 acres (see RE60-EE).

This high-level analysis assumes a constant percent reduction in energy consumption throughout all hours of the year and does not consider the costs of the ECMs. Actual energy efficiency measures are likely to impact the load profile in different ways, as are other demand-side factors, to be assessed in Phase III.

\section{Discussion: Potential Next Steps Incorporating Load Increases, Load Reductions, and Deferrable Loads}

Especially for an island energy system like Catalina, effectively managing energy loads and consumption can have a significant impact on energy generation strategies and assets, provide an opportunity to lower overall LCC, and facilitate achievement of environmental protections. For example, implementation of ECMs could reduce the amount of generation capacity needed and possibly the distribution infrastructure required as illustrated in the initial EE scenario described in Section 3.2.5 above and many other actual examples from the EE and DR industry.

Additionally, controls to manage deferrable loads on the island could be resources for the island electricity system. Integration of these controllable deferrable loads could result in more optimal cost-effective generation strategies and selection of capital infrastructure. On the other hand, the 
potential for increasing loads from cruise ships, building and transportation electrification, can also have a significant impact on future power generation scenarios.

The techno-economic analysis described in this document is primarily focused on supply-side generation options, except for the one EE example listed above. A potential future phase III could incorporate additional techno-economic analysis to evaluate how the energy system could be optimized with consideration of both demand and supply-side considerations.

NV5 has conducted a high-level analysis on the EE and DR potential on Catalina Island to assess opportunities to cost-effectively reduce load and emissions and positively influence the island's load profile. The results of this assessment completed by NV5 could be used as technical inputs for a techno-economic EE and DR model to determine the impact to the generation options. Additional utility systems data inputs from SCE and others could also be used to evaluate other load increases and deferrable loads as outlined in Table 5.

Table 5. Potential Future Load Changes for Phase III

\begin{tabular}{lll}
\hline \multicolumn{1}{l}{ Load Increases } & Load Reductions & Deferrable Loads \\
\hline - Building electrification & Energy efficiency & - Demand response \\
- Electrification of & measures & - Load shifting \\
vehicles & & - Water desalination plant \\
Cruise ship shore & Island-wide water pumping \\
power & & - Electric crane and rock \\
& & crusher \\
\hline
\end{tabular}

Moreover, future analyses could evaluate the impacts to the generation strategies resulting from the ability to control deferrable loads (e.g., grid interactive water heaters, air conditioning, ice storage for air conditioning, water pumps, water desalination) to determine their impact on energy generation strategies. The impact of deferrable loads on the load profile may be stacked in addition to the EE and DR impact described above.

Because SCE is also the potable water utility for Catalina Island, managing a system of groundwater wells and an existing and expanding desalination plant, they are in a good position to invest in operational and infrastructure improvements to enhance the efficiency of the energy and water systems. This water-energy nexus scenario warrants attention and analysis to provide additional insights for SCE consideration to improve the scheduling, operation, and construction of desalination, water treatment, and water distribution assets (another entity manages the wastewater system).

A key to improving energy generation strategies associated with water treatment and conveyance is to separate the operation of the treatment plant from the water demand that it is serving. This could be achieved by expanding the size of the treatment plant and adding storage in the form of water tanks. Storing water in tanks is very similar in concept to storing energy in batteries, except it is lossless and could be accomplished at a lower cost. Moreover, the variable nature of renewable energy can be synergistic with such dispatchable loads - water could also be treated during periods of high renewable energy production and stored for later use. 
A techno-economic analysis could evaluate this water-energy nexus scenario. Modeling would help identify cost-effective technologies, sizes, and operational strategies for reducing overall system ownership costs.

Future Phase III analyses could also consider the impact of generation strategies resulting from increases to the load profile. One significant impact to the load profile could be cruise ships using shore power. A second potential impact could be the development of an electric transportation (vehicle/boat) charging program. This analysis could also evaluate how an electric transportation charging program could impact and be complimentary to the generation strategy. A third potential load increase could be from the complete removal of propane from buildings, followed by replacement with electricity. Similarly, the impact of the increases to loads on the load profile may be stacked in addition to the other load impacts described above.

In summary, a phase III techno-economic analysis and modeling of load increases, decreases, and deferrable loads could provide useful information to facilitate decisions on programs, policies, operational practices, and infrastructure investments on Catalina Island to improve the overall effectiveness and efficiency of the energy, water, buildings, and transportation systems.

\section{Summary}

Phases I and II of NREL's techno-economic analysis of generation and storage options for Catalina Island suggests that a mix of on-island diesel and/or propane generators, solar PV, and BESS could provide the island with cost-effective electricity in alignment with emissions standards and SCE's clean and reliable energy goals.

The results for Phases I and II of this primarily generation-side analysis can inform SCE's planning and permitting decisions for near-term regulatory compliance and can inform future decisions and/or a phased implementation of technologies. Further techno-economic analysis of the generation-side implications of demand-side considerations, including load increases, load reductions, and deferrable/controllable loads is warranted. 


\section{Glossary}

\section{Term}

Area cost factor

Capital and

replacement costs

Fuel costs

Life cycle costs

Non-fuel operations and maintenance costs

Present Value of

Revenue Requirement

(PVRR) factor

\section{Definition}

The ACF applies to capital and non-fuel O\&M costs to account for the increased costs associated with doing business on an island rather than the U.S. mainland.

Capital and replacement cost estimates attempt to capture the fully burdened installed cost of the system, including purchased assets, infrastructure, and installation. The Appendix and text throughout this document attempt to capture the degree of certainty/uncertainty about each individual technology's capital/replacement costs at Catalina and whether the estimates used are average, liberal, or conservative. Replacement costs are only considered for technologies with expected lives shorter than the 30-year analysis period.

Fuel costs attempt to incorporate both the cost of the fuel and transport of the fuel to the island. There is still an element of uncertainty about fuel transport costs.

LCC include the present value of capital costs, replacement costs, fuel costs, non-fuel O\&M costs, and mainland electricity purchase costs as defined here and throughout the Appendix. REopt optimization seeks to minimize the LCC of electricity at Catalina Island by identifying cost-optimal generation and storage system sizes and dispatch to achieve a given energy goal.

Non-fuel O\&M costs attempt to capture the cost of operating and maintaining the energy systems at Catalina. Note that the O\&M costs included in the techno-economic analysis capture costs that scale with increased generation and storage capacity $(\$ / \mathrm{kW})$ or production $(\$ / \mathrm{kWh})$, as specified in the Appendix. Additional fixed O\&M costs such as those to operate and maintain the electricity distribution system may exist as well but are not included.

PVRR is an SCE metric similar to net present value that incorporates the costs and value to rate payers over the project life. PVRR capital cost scaling factors were provided by SCE to account for the way rate payers pay for a project. These scaling factors are technology-specific, calculated by SCE based on assumptions about capital cost, number of years required to permit and build each technology, build year (assumed 2021), land costs (none included in this analysis since Phase II analysis assumes land is leased), incentives (i.e., federal investment tax credit [ITC] 
and Modified Accelerated Cost Recovery System [MACRS] depreciation), and decommissioning costs. 


\section{References}

California ISO (2020). "Market Price Maps.” Accessed August 10, 2020.

http://www.caiso.com/PriceMap/Pages/default.aspx.

Carbon Tracking Ltd. (2008). "A study of the carbon footprint of car transport with Irish

Ferries." http://www.carbontracking.com/reports/irish_ferries_emissions_calculation.pdf.

Catalina Chamber of Commerce (2020). "Island Info.” Accessed August 7, 2020.

https://www.catalinachamber.com/.

Cutler, D., Olis, D., Elgqvist, E., Li, X., Laws, N., DiOrio, N., Walker, A., and K. Anderson (2017). REopt: A Platform for Energy System Integration and Optimization. Golden, CO:

National Renewable Energy Laboratory. https://www.nrel.gov/docs/fy17osti/70022.pdf.

EIA (2020). "Annual Energy Outlook for Pacific region (commercial, 2020-2050).” Accessed August 10, 2020. https://www.eia.gov/outlooks/aeo/data/browser/.

International Renewable Energy Agency (2017). "Electricity Storage and Renewables: Costs and Markets to 2030." Abu Dhabi: International Renewable Energy Agency. https://www.irena.org//media/Files/IRENA/Agency/Publication/2017/Oct/IRENA_Electricity_Storage_Costs_2017.pdf.

NASA (2020). "Modern-Era Retrospective analysis for Research and Applications (MERRA)." Accessed August 10, 2020. https://gmao.gsfc.nasa.gov/reanalysis/MERRA/.

NREL (2019). “NREL Annual Technology Baseline (ATB) 2019.” Accessed August 10, 2020. https://atb.nrel.gov/electricity/2019/index.html.

NREL (2020a). "REopt: Renewable Energy Integration \& Optimization." Accessed August 7, 2020. https://reopt.nrel.gov/.

NREL (2020b). "National Radiation Solar Database.” Accessed August 10, 2020. https://nsrdb.nrel.gov/.

NREL (2020c). “Wind Integration National Dataset Toolkit.” Accessed August 10, 2020. https://www.nrel.gov/grid/wind-toolkit.html.

NREL (2020d). “Land Use by System Technology.” Accessed August 10, 2020. https://www.nrel.gov/analysis/tech-size.html.

NV5 (2020). Map of SCE distribution system on Catalina Island.

Olmer, N., Comer, B., Roy, B., Mao, X., and D. Rutherford (2017). Greenhouse Gas Emissions From Global Shipping, 2013-2015. Washington, DC: The International Council on Clean Transportation.

Ong, S., Campbell, C., Denholm, P., Margolis, R., and G. Heath (2013). Land-Use Requirements for Solar Power Plants in the United States. Golden, CO: NREL.

https://www.nrel.gov/docs/fy13osti/56290.pdf. 
Patsios, C., Wu, B., Chatzinikolaou, E., Rogers, D., Wade, N., Brandon, N., and P. Taylor (2016). "An integrated approach for the analysis and control of grid connected energy storage systems." Journal of Energy Storage (5); pp. 48-61.

SCAQMD (2018). Rule 1135. Emissions of Oxides of Nitrogen from Electricity Generating Facilities. http://www.aqmd.gov/docs/default-source/rule-book/reg-xi/rule-1135.pdf.

SCE (2017). The Clean Power and Electrification Pathway: Realizing California's Environmental Goals. Rosemead, CA: Southern California Edison.

https://www.edison.com/content/dam/eix/documents/our-perspective/g17-pathway-to-2030white-paper.pdf.

ScienceDirect (2020). "Sodium Sulfur Battery.” Accessed August 10, 2020. https://www.sciencedirect.com/topics/engineering/sodium-sulfur-battery.

U.S. Coast Guard (2020). "United States Coast Guart Merchant Vessels of the United States." Accessed August 10, 2020. https://www.dco.uscg.mil/Our-Organization/Assistant-Commandantfor-Prevention-Policy-CG-5P/Inspections-Compliance-CG-5PC-/Office-of-InvestigationsCasualty-Analysis/Merchant-Vessels-of-the-United-States/.

Winnes, H. and E. Fridell (2012). "Particle Emissions from Ships: Dependence on Fuel." Journal of the Air \& Waste Management Association 1391-1398. https://www.tandfonline.com/doi/pdf/10.3155/1047-3289.59.12.1391.

Wood Mackenzie (2020). "U.S. Energy Storage Monitor: 2019 Year-in-Review.” Annapolis, MD: Wood Mackenzie. 


\section{Appendix}

This Appendix describes the techno-economic assumptions used in NREL's energy systems analysis for Catalina Island. The assumptions listed in this section were used for each scenario of Phase II except in sensitivity analyses where assumptions were varied, such as in the Lower PV and BESS CAPEX sensitivity scenario and in the Land Lease Cost sensitivity scenario.

\section{A.1 General Economic Assumptions}

This section describes the general economic assumptions used to evaluate the LCC of the various scenarios and configurations described in the body of the report.

Table 6. Economic Assumptions

\begin{tabular}{lll}
\hline Input & Assumption & Reference \\
\hline Ownership model & $\begin{array}{l}\text { Direct ownership } \\
\text { by SCE }\end{array}$ & Per SCE \\
Analysis period & 30 years & $\begin{array}{l}\text { 2019 Annual Technology Baseline (ATB) (NREL } \\
\text { 2019) and to match previous SCE analysis for } \\
\text { Catalina }\end{array}$ \\
\hline Discount rate (nominal) & $10 \%$ & Per SCE \\
\hline Inflation rate & $2.5 \%$ & 2019 ATB (NREL)
\end{tabular}

a Standardized assumptions based on NV5 study of generator options for Catalina; actual generator capital costs will likely vary based on generator type, capacity, and configuration, as discussed in Section 3.

\section{A.2 Technology Assumptions}

Table 8 summarizes the technical and cost assumptions for the undersea cable, diesel, propane and LNG generators, solar PV, wind turbines, and BESS. Wave cost and performance assumptions are not listed because they were provided to SCE by a wave energy device vendor and could not be verified by NREL.

Included in this breakout of costs are two cost multipliers - the ACF and the PVRR factor.

- The ACF is a multiplier applied to capital and O\&M costs to account for increases in costs because of higher labor and transportation/shipment costs to complete capital construction projects on Catalina Island. To determine the ACF for each technology, it was assumed that on-island construction costs 2.5 times the mainland costs, but engineering services and materials can be purchased at mainland costs. For the undersea cable and generators, NV5 explicitly identified line items that would likely incur this $2.5 \mathrm{x}$ multiplier, and these costs were included in the estimate provided by NV5. For PV and wind, it was assumed that $51 \%$ of estimated mainland capital costs would incur this $2.5 x$ multiplier, for an overall ACF of 1.765 . For BESS, it was assumed that only $21 \%$ of estimated mainland costs would incur this 2.5x multiplier, for an overall ACF of 1.315 .

- SCE's PVRR factors apply only to capital and replacement costs and help capture the cost of these technologies to the rate payer, considering that rate payers pay for capital expenses over a number of years rather than the year the costs are incurred to the utility. 
PVRR multipliers are technology-specific and calculated by SCE based on capital cost, land purchase costs (none were included in PVRR factor calculation for this analysis because Phase II analysis assumes land is leased at $\$ 200 /$ acre rather than purchased), incentives (such as the federal ITC and MACRS depreciation available to RE and BESS technologies), ACF, estimated build year, estimated number of years required to permit and build each technology, and, if available, estimated decommissioning costs.

Distribution system upgrade costs required to facilitate higher variable RE penetrations were estimated by SCE at $\$ 1.2$ million/mile. NV5 estimated how much distribution line would require upgrades to facilitate different levels of variable RE penetration, based on representative site selection, and estimated costs for new distribution line poles. These costs, listed in Table 7, were included in REopt analysis and results.

Table 7. Representative Distribution System Upgrade Cost Estimate

\begin{tabular}{ccc}
\hline Maximum PV Capacity (MW-DC) & $\begin{array}{c}\text { Distance to Upgrade } \\
\text { (miles) }\end{array}$ & $\begin{array}{c}\text { Estimated Distribution System } \\
\text { Upgrade Costs }\end{array}$ \\
\hline 3.8 & 0 & $\$ 0$ \\
6.2 & 4.7 & $\$ 5.64$ million \\
9.5 & 8.4 & $\$ 10.08$ million \\
15.6 & 9.2 & $\$ 11.04$ million \\
\hline
\end{tabular}

Source: NV5 
Table 8. Summary of Techno-Economic Assumptions

\begin{tabular}{|c|c|c|c|c|c|c|c|c|c|}
\hline & & $\begin{array}{c}\text { Undersea } \\
\text { Cable }\end{array}$ & $\begin{array}{c}\text { Diesel } \\
\text { Generators }\end{array}$ & $\begin{array}{l}\text { Propane } \\
\text { Generators }\end{array}$ & $\begin{array}{c}\text { LNG } \\
\text { Generators }\end{array}$ & Solar PV & $\begin{array}{l}\text { Wind } \\
\text { Turbines }\end{array}$ & $\begin{array}{l}\text { Existing } \\
\text { BESS }\end{array}$ & New BESS \\
\hline \multirow{4}{*}{ 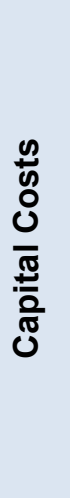 } & $\begin{array}{l}\text { Before multipliers } \\
\text { (\$/W-AC, unless } \\
\text { otherwise noted) }\end{array}$ & --- & $\$ 3.294^{a}$ & $\begin{array}{c}\$ 6.920 \\
\text { standalone, } \\
\$ 9.393 \text { for all- } \\
\text { propane }^{\mathrm{a}}\end{array}$ & $\$ 11.283^{\mathrm{a}}$ & $\$ 1.612 / \mathrm{W}-\mathrm{DC} b$ & $\$ 3.500^{c}$ & --- & $\begin{array}{c}\$ 401 / \mathrm{kWh}+ \\
\$ 688 / \mathrm{kW}^{\mathrm{d}}\end{array}$ \\
\hline & $\mathrm{ACF}$ & --- & \multicolumn{3}{|c|}{ Included in capital cost estimate ${ }^{a}$} & 1.765 & 1.765 & --- & 1.315 \\
\hline & PVRR factor & --- & $1.04^{\mathrm{e}}$ & $1.17^{f}$ & $1.17^{f}$ & $0.93^{9}$ & $1.08^{f}$ & --- & $0.87^{\mathrm{h}}$ \\
\hline & $\begin{array}{l}\text { Including } \\
\text { multipliers (\$/W- } \\
\text { AC, unless } \\
\text { otherwise noted) }\end{array}$ & $\$ 220 M^{i}$ & $\$ 3.426$ & $\begin{array}{l}\$ 8.166 \\
\text { standalone, } \\
\$ 10.990 \text { for } \\
\text { all-propane }\end{array}$ & $\$ 13.201$ & $\$ 2.646 / \mathrm{W}-\mathrm{DC}$ & $\$ 6.672$ & --- & $\begin{array}{c}\$ 459 / \mathrm{kWh}+ \\
\$ 787 / \mathrm{kW}\end{array}$ \\
\hline \multirow{5}{*}{ 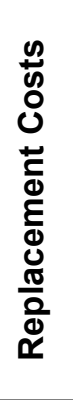 } & Year & --- & --- & --- & --- & --- & --- & Year $10^{\mathrm{j}}$ & Year $10^{k}$ \\
\hline & $\begin{array}{l}\text { Cost before } \\
\text { multipliers }\end{array}$ & --- & --- & --- & --- & --- & -- & $\begin{array}{l}\$ 213 / \mathrm{kWh}+ \\
\$ 1,700 / \mathrm{kW}\end{array}$ & $\begin{array}{c}\$ 193 / \mathrm{kWh}+ \\
\$ 332 / \mathrm{kWm}^{\mathrm{m}}\end{array}$ \\
\hline & ACF & --- & --- & --- & --- & --- & --- & 1.315 & 1.315 \\
\hline & PVRR factor & --- & --- & --- & --- & --- & --- & $0.37^{\mathrm{h}}$ & $0.37^{\mathrm{h}}$ \\
\hline & $\begin{array}{l}\text { Including } \\
\text { multipliers }\end{array}$ & --- & --- & --- & --- & --- & --- & $\begin{array}{c}\$ 104 / \mathrm{kWh}+ \\
\$ 827 / \mathrm{kW}\end{array}$ & $\begin{array}{c}\$ 94 / \mathrm{kWh}+ \\
\$ 162 / \mathrm{kW}\end{array}$ \\
\hline \multirow{3}{*}{ 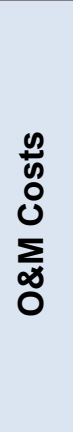 } & $\begin{array}{l}\text { Before multipliers } \\
\text { (\$/kW-AC/year, } \\
\text { unless otherwise } \\
\text { noted) }\end{array}$ & --- & $\$ 150^{n}$ & $\$ 150^{n}$ & $\$ 150^{n}$ & $\$ 16 / k W-D C / y e a r^{b}$ & $\$ 50^{c}$ & --- & --- \\
\hline & ACF & --- & 1.765 & 1.765 & 1.765 & 1.765 & 1.765 & --- & --- \\
\hline & $\begin{array}{l}\text { Including } \\
\text { multipliers (\$/kW- } \\
\text { AC/year, unless } \\
\text { otherwise noted) }\end{array}$ & $\$ 5 M^{i}$ & $\$ 265$ & $\$ 265$ & $\$ 265$ & $\$ 28$ & $\$ 88$ & --- & --- \\
\hline
\end{tabular}

This report is available at no cost from the National Renewable Energy Laboratory (NREL) at www.nrel.gov/publications. 


\begin{tabular}{|c|c|c|c|c|c|c|c|c|c|}
\hline & & $\begin{array}{l}\text { Undersea } \\
\text { Cable }\end{array}$ & $\begin{array}{c}\text { Diesel } \\
\text { Generators }\end{array}$ & $\begin{array}{l}\text { Propane } \\
\text { Generators }\end{array}$ & $\begin{array}{l}\text { LNG } \\
\text { Generators }\end{array}$ & Solar PV & $\begin{array}{l}\text { Wind } \\
\text { Turbines }\end{array}$ & $\begin{array}{l}\text { Existing } \\
\text { BESS }\end{array}$ & New BESS \\
\hline \multirow{6}{*}{ 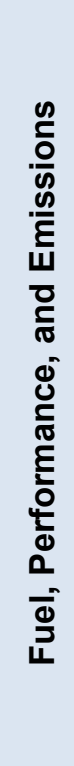 } & $\begin{array}{l}\text { Fuel cost } \\
\text { (\$/MMBTU, } \\
\text { unless otherwise } \\
\text { noted) }\end{array}$ & $\begin{array}{l}\text { Average of } \\
\$ 40.97 / \mathrm{MWh} \\
\text { electricity }^{\circ}\end{array}$ & $\$ 18.93^{p}$ & $\$ 17.35^{p}$ & $\$ 16.93^{q}$ & --- & --- & --- & --- \\
\hline & $\begin{array}{l}\text { Heat rate } \\
(\mathrm{BTU} / \mathrm{kWh})\end{array}$ & --- & $\begin{array}{c}8,854^{a}- \\
9,726^{r}\end{array}$ & $9,688^{a}$ & $8,645^{a}$ & --- & --- & --- & --- \\
\hline & $\begin{array}{l}\text { Fuel cost } \\
\text { escalation rates } \\
\text { (\%/year) }\end{array}$ & $2.76 \%$ & $3.00 \%$ & $3.35 \%$ & $3.69 \%$ & --- & --- & --- & --- \\
\hline & $\begin{array}{l}\text { Capacity factor } \\
\text { for RE resource } \\
(\%)\end{array}$ & --- & --- & --- & --- & $21.7 \%^{\mathrm{t}}$ & $9.9 \%$ u & --- & --- \\
\hline & $\begin{array}{l}\text { BESS round-trip } \\
\text { efficiency }\end{array}$ & --- & --- & --- & --- & --- & --- & $70 \%$ & $89.9 \%^{k}$ \\
\hline & $\begin{array}{l}\text { NOx emissions } \\
\text { (gm/HP-hour) }\end{array}$ & Varies & $0.46^{b}-0.66^{n}$ & $0.10^{\mathrm{b}}$ & $0.024^{b}$ & --- & --- & --- & --- \\
\hline \multirow{2}{*}{ ర్ర } & $\begin{array}{l}\text { Installed capacity } \\
\text { density }\end{array}$ & --- & --- & --- & --- & 9.1 acres/MW-DC & $\begin{array}{c}30 \\
\text { acres/MW- } \\
\mathrm{AC}^{\mathrm{w}}\end{array}$ & --- & --- \\
\hline & $\begin{array}{l}\text { Land lease cost }{ }^{\mathrm{x}} \\
\text { (\$/acre/year) }\end{array}$ & --- & --- & --- & --- & $\$ 200$ & --- & --- & --- \\
\hline \multicolumn{2}{|c|}{ General/Other } & --- & $\begin{array}{l}\text { 1.49, } 2.23 \\
\& 2.98 \mathrm{MW} \\
\text { units }^{\mathrm{a}} ; \\
\text { Minimum } \\
\text { load: } 50 \%{ }^{\mathrm{a}}- \\
80 \% \mathrm{~m}^{\mathrm{m}} \text { of } \\
\text { rated } \\
\text { capacity }\end{array}$ & $\begin{array}{c}1.38 \mathrm{MW} \\
\text { units }^{\mathrm{a}} ; \\
\text { Minimum load: } \\
50 \% \text { of rated } \\
\text { capacity }^{\mathrm{a}}\end{array}$ & $\begin{array}{l}2.5 \mathrm{MW} \\
\text { unitsa; } \\
\text { Minimum } \\
\text { load: } 50 \% \\
\text { of rated } \\
\text { capacity }\end{array}$ & $\begin{array}{l}\text { Tilt: latitude }\left(33.4^{\circ}\right) ; \\
\text { Azimuth: South-facing; } \\
\text { DC-to-AC ratio: } 1.2 ; \\
\text { Inverter efficiency: } 96 \% \text {; } \\
\text { Annual degradation: } \\
0.5 \% / \text { year }\end{array}$ & $\begin{array}{c}100-275 \\
\mathrm{~kW} \\
\text { turbines }^{c}\end{array}$ & $\begin{array}{c}1 \mathrm{MW}, 7.2 \\
\text { MWh NaSj; } \\
\text { Minimum } \\
\text { state of } \\
\text { charge: } 10 \% \mathrm{j}\end{array}$ & $\begin{array}{l}\text { Lithium-ion } \\
\text { (Li-ion)y; } \\
\text { Minimum } \\
\text { state of } \\
\text { charge: } \\
20 \%{ }^{k}\end{array}$ \\
\hline
\end{tabular}

a Standardized assumptions based on NV5 study of generator options for Catalina; actual generator capital costs will likely vary based on generator type, capacity, and configuration, as discussed in Section 3.

b Source: NREL 2019

This report is available at no cost from the National Renewable Energy Laboratory (NREL) at www.nrel.gov/publications. 
${ }^{c}$ Distributed wind energy cost estimate provided by NREL wind expert.

d Source: Wood Mackenzie 2020

e Source: SCE. Assumes 10/30/30/30 spend in 2020-2023, commercial operation date (COD) 2021-2023

f Source: SCE. Assumes 50/50 spend in 2020-2021, COD 2021

g Source: SCE. Assumes COD of 2021

h Source: SCE. Assumes battery is connected to PV installations for tax purposes, COD 2021 with replacement COD 2031

i NV5 rough order of magnitude cost estimate for undersea cable.

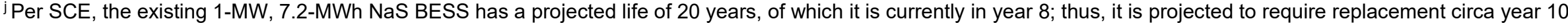

of the analysis period. Per SCE, the overall round-trip efficiency is approximately $70 \%$ and it operates with a minimum state of charge of $10 \%$.

k Source: Patsios et al. 2016

'Source: ScienceDirect 2020

m Source: International Renewable Energy Agency (2017).

n Capacity-based O\&M costs (e.g., $\$ / \mathrm{kW}$ ) were estimated as $60 \%$ of total recorded O\&M costs, in line with numbers NREL has seen elsewhere.

- Mainland generation was modeled at California Independent System Operator (CAISO) day-ahead locational marginal pricing for Huntington Beach Substation

(08/21/2018-08/20/2019); average of \$40.97/MWh, maximum of \$255.82/MWh (California ISO 2020).

$p$ Diesel and propane fuel costs were calculated from SCE 2017 average fuel prices for Catalina Island, including the cost of transportation.

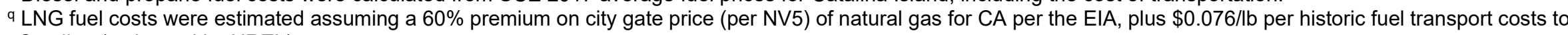
Catalina (estimated by NREL).

$r$ The fuel curve and NOx emissions for the existing diesel generator Unit 15 that is exempt from SCAQMD emissions requirements were obtained from SCE historical operational data.

s Calculated from EIA Annual Energy Outlook for Pacific region (EIA 2020)

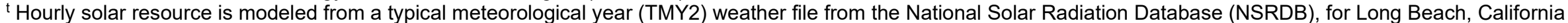
(NREL 2020b).

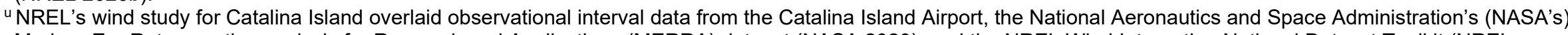
Modern-Era Retrospective analysis for Research and Applications (MERRA) dataset (NASA 2020), and the NREL Wind Integration National Dataset Toolkit (NREL

2020c). This techno-economic analysis utilized the resource data for the strongest sites identified at $55 \mathrm{~m}$ hub height.

$\checkmark$ Source: Ong et al. 2013

w Source: NREL 2020d

x SCE provided a cost estimate on the market value of land on Catalina. This cost was applied to solar PV because PV has a relatively defined land use requirement.

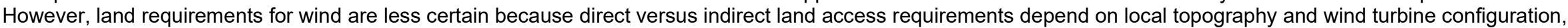

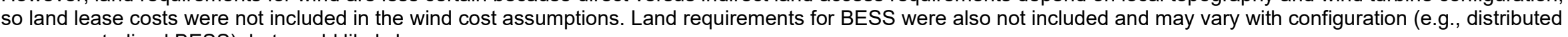
versus centralized BESS), but would likely be necessary.

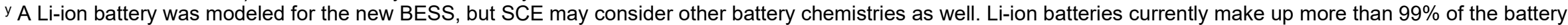
storage market (Wood Mackenzie 2020).

This report is available at no cost from the National Renewable Energy Laboratory (NREL) at www.nrel.gov/publications. 


\section{A.3 Reliability Requirements}

System capacity-based and operational reliability requirements were included in the modeling.

For the capacity-based requirement the model required an $\mathrm{N}+2$ redundancy. To satisfy this requirement, at peak load, if the two largest generators are off-line the remaining generators must be able to carry the peak load. The model conservatively only considers fossil fuel generation capacity towards this required redundancy; RE and BESS were not considered to support $\mathrm{N}+2$ capacity requirements because they are not always available to provide coverage (PV and wind power are dependent on solar or wind resource and a battery at a low state of charge may not be able to sustain a load). Nonetheless, RE and BESS could provide additional redundancy to the system.

For the operational reliability requirement of spinning reserve, the analysis required that in each hourly time step, the spinning reserve be greater than or equal to the sum of the following:

- $10 \%$ of the load in the current time step

- $80 \%$ of solar PV output in the current time step

- $50 \%$ of wind output in the current time step.

This spinning reserve could be provided by any of the following:

- Unused capacity of online (operational) fossil fuel generators

- Battery storage, up to the minimum power the BESS could provide for the hour time step

- A percentage of PV and wind generation that is being curtailed or sent to battery storage ( $20 \%$ for solar PV, $50 \%$ for wind).

\section{A.4 Fuel Shipments and Associated Emissions}

\section{Current Emissions from Fuel Shipments}

SCE currently consumes approximately 2.03 million gallons of diesel fuel and 150,000 gallons of propane to fuel Catalina's electricity generation with diesel reciprocating generators and propane microturbines, respectively. Per SCE, the microturbines will not be replaced when they reach the end of life in the next several years. Currently, microturbines only consume approximately $20 \%$ of propane delivered to Catalina; the rest is distributed to facilities in the Avalon area. 
SCE imports diesel and propane for energy generation on Catalina Island from a mainland port in Long Beach, California. Annual shipments in 2017 included 89 propane tankers $(9,000$ gal/tanker) and 282 diesel tankers (7,200 gal/tanker). The fuel is shipped to the island along with other goods (ship fuel, groceries, construction materials, other cargo) by Avalon Freight Services using one of two vessels: the Catalina Provider (primary ship) or the Lucy Franco (A. Valdez, personal communication; U.S. Coast Guard 2020). Fuel comprises approximately 55\% of each shipload by weight (SCE, unpublished 2017 fuel shipment cost data provided to authors). Both vessels run on marine diesel oil (MDO) (Abelino Valdez, personal communication).

Based on the energy intensity and emissions assumptions listed in Table 9, annual NOx and carbon dioxide $\left(\mathrm{CO}_{2}\right)$ emissions associated with fuel shipments to Catalina are estimated at 21 tons NOx/year and 569 tons $\mathrm{CO}_{2}$ /year (Winnes and Fridell 2012; Olmer et al. 2017; Carbon Tracking Ltd. 2008).

Table 9. Vessel and Emissions Data for Fuel Shipments to Catalina Island

\begin{tabular}{|c|c|c|c|}
\hline Vessel & Catalina Provider & Lucy Franco & \\
\hline Engines & 3 C18 tier 3 engines & 2 C32 tier 3 engines & \\
\hline Horsepower (hp) & 1800 & 1200 & \\
\hline Boat Weight & 192,000 lbs. (96.0 tons) & $\begin{array}{l}194,000 \mathrm{lbs} .(97.0 \\
\text { tons) }\end{array}$ & \\
\hline Trips/Year (estimated) & 200 & 60 & \\
\hline MDO Used Per Round Trip & $\begin{array}{l}350(440-660 \text { at } \\
\text { maximum } \mathrm{hp})\end{array}$ & $\begin{array}{l}350(440-660 \text { at } \\
\text { maximum } \mathrm{hp})\end{array}$ & \\
\hline $\begin{array}{l}\text { NOx Emissions Rate } \\
\text { (pounds (lbs.) NOx/gal MDO) }\end{array}$ & 0.4655 & 0.4655 & \multirow[b]{3}{*}{ Total Emissions } \\
\hline $\begin{array}{l}\mathrm{CO}_{2} \text { Emissions Rate } \\
\text { (lbs./ } / \mathrm{CO}_{2} \text { per gal/MDO) }\end{array}$ & 22.747 & 22.747 & \\
\hline & & & \\
\hline $\begin{array}{l}\text { Annual NOx Emissions } \\
\text { (tons) }\end{array}$ & 16 & 5 & 21 \\
\hline Annual $\mathrm{CO}_{2}$ Emissions (tons) & 438 & 131 & 569 \\
\hline
\end{tabular}

Assumptions include the following: 7.8 tankers shipped per week (1.6 tankers/trip, 342,000 lbs./week), four tankers maximum per vessel, five trips per week; MDO density: 0.9 kg/L; MDO heat content: 18,358 BTU/lb.; 55\% of cargo weight is fuel; thus, $55 \%$ of ship emissions are attributed to fuel shipments (SCE, unpublished 2017 fuel shipment cost data provided to authors; A. Valdez, personal communication; A. Mardesich, personal communication). Fuel shipment analysis focuses on delivering equal heat content to the island but does not consider differences in generator efficiency.

\section{Fuel Switching Impact on Emissions from Fuel Shipments}

Because propane generators produce lower emissions than diesel generators, switching Catalina's generators to run on propane fuel could yield direct emissions reductions, including, as discussed in the main text, NOx savings amounting to approximately 19 tons per year. An analysis of the additional indirect emissions impacts of fuel switching includes consideration of emissions from transporting fuel to the island.

To fully replace diesel generation with propane generation, Catalina would need approximately 13 million lbs. of propane, or 344 tankers per year in addition to the 89 propane tankers currently shipped (433 total, an increase of 63 tankers per year). Fuel shipping charges are applied primarily by weight, costing approximately $\$ 0.052 / \mathrm{lb}$. (SCE, unpublished 2017 fuel shipment cost data provided to authors). Because propane has a higher heat content by weight, 1,406,000 
fewer pounds would need to be shipped, which could save SCE approximately $\$ 73,000$ /year while reducing emissions from fuel shipments by 1.6 tons of $\mathrm{NOx}$ and 45 tons of $\mathrm{CO}_{2}$ annually (Olmer et al. 2017; Winnes and Fridell 2012; Carbon Tracking Ltd. 2008).

However, a higher number of propane tankers than diesel tankers would need to be shipped, possibly necessitating more trips to and from Catalina. Assuming the 2 freight vessels currently operate at capacity, it will take approximately 16 additional trips to ship the additional 63 tankers of propane needed (A. Valdez, personal communication). This represents an increase of 1.3 tons of NOx/year and 64 tons $\mathrm{CO}_{2}$ /year (Olmer et al. 2017; Winnes and Fridell 2012; Carbon Tracking Ltd. 2008).

Table 10. Summary of Results from Fuel Switching Shipment Analysis

\begin{tabular}{lll}
\hline $\begin{array}{l}\text { Current } \\
\text { Case }\end{array}$ & Current Shipments & 371 tankers shipped per year \\
& Current Emissions & 21 tons NOx/year \\
\hline $\begin{array}{l}\text { Changes } \\
\text { from }\end{array}$ & Cost & $\$ 73,000$ shipping savings \\
$\begin{array}{l}\text { Fuel } \\
\begin{array}{l}\text { Switching } \\
\text { to Propane }\end{array}\end{array}$ & Tankers & 63 more tankers to ship \\
& & $\mathrm{NOx}:-1.6$ to +1.3 tons/year \\
$\mathrm{CO}_{2}:-45$ to +64 tons/year
\end{tabular}

\footnotetext{
Assumptions include the following: 1 diesel tanker holds 7,200 gallons; 1 propane tanker holds 9,000 gallons. Diesel density: $7.1 \mathrm{lbs} . / \mathrm{gal}$. Propane density: $4.2 \mathrm{lbs} /$ gal. Fuel heat content of diesel: 13,900 BTU/gal, 19,553 BTU/lb. Fuel heat content of propane: 91,000 BTU/gal, 21,667 BTU/lb. (A. Valdez, personal communication).
} 